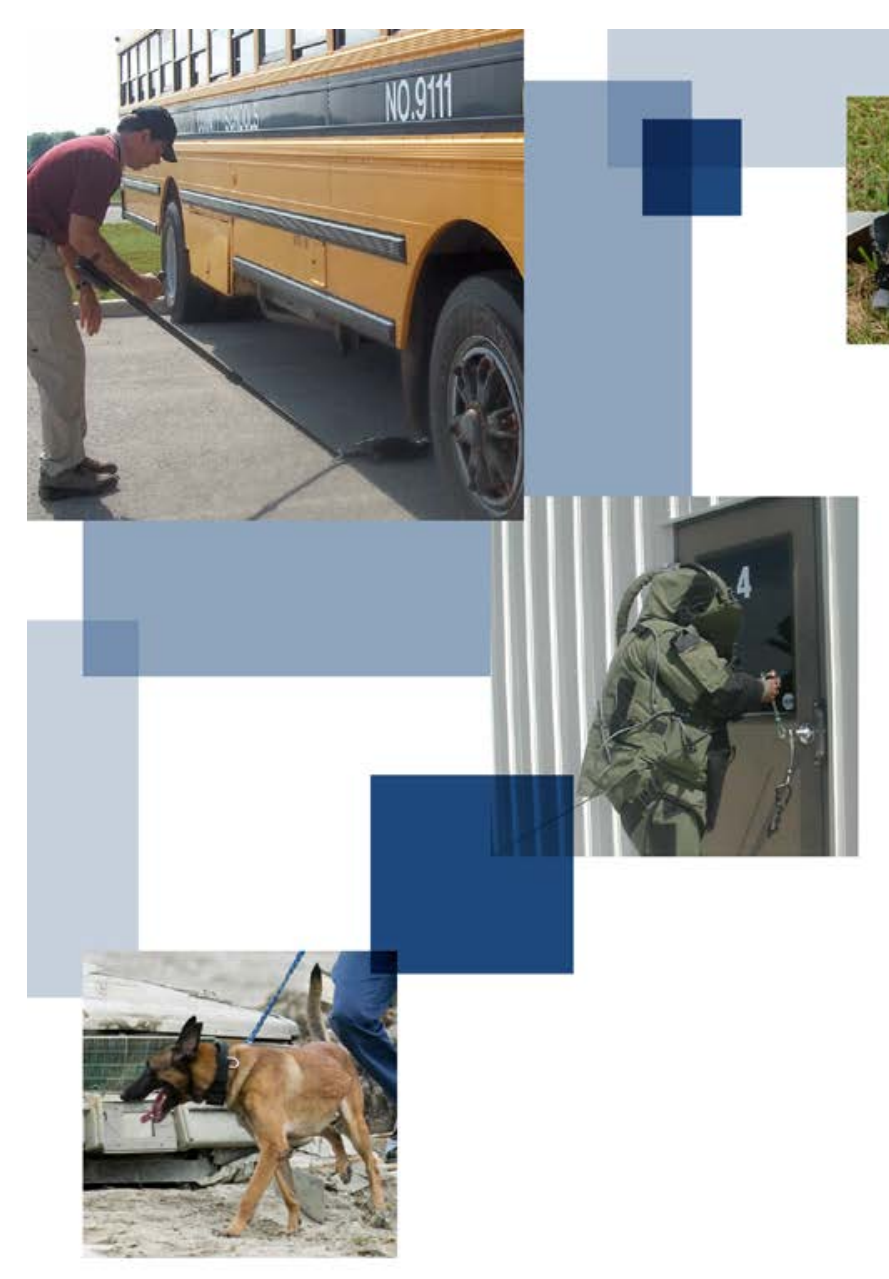

NISTIR 7919
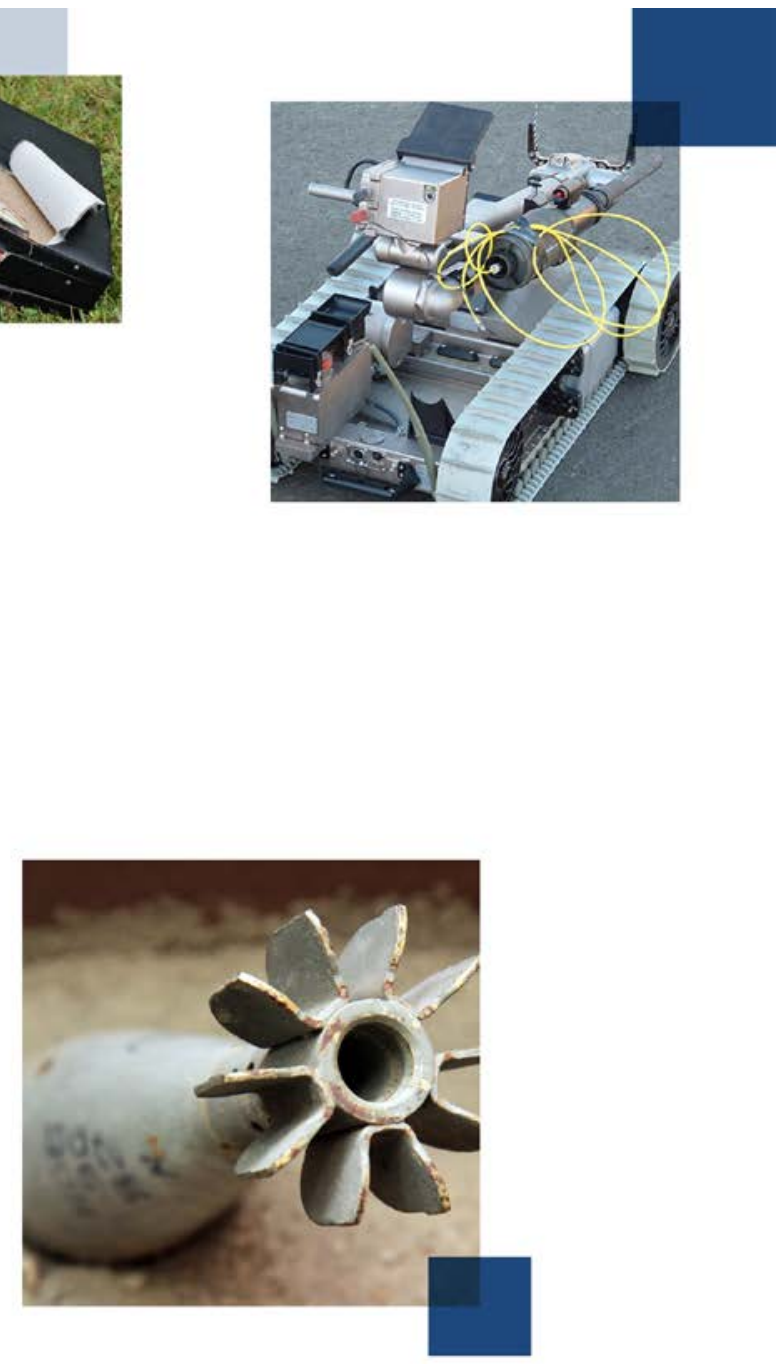

\title{
EXPLOSIVES STANDARDS FORUM RECOMMENDATIONS
}

\author{
WILLIAM G. BILLOTTE \\ SHARON B. NAKICH
}

March 2013

http://dx.doi.org/10.6028/NIST.IR.7919

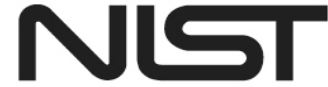

National Institute of Standards and Technology

U.S. Department of Commerce 
NISTIR 7919

\title{
Explosives Standards Forum Recommendations
}

\author{
William G. Billotte \\ Office of Special Programs \\ Laboratory Programs \\ Sharon B. Nakich \\ Science Applications International Corporation \\ McLean, VA
}

http://dx.doi.org/10.6028/NIST.IR.7919

March 2013

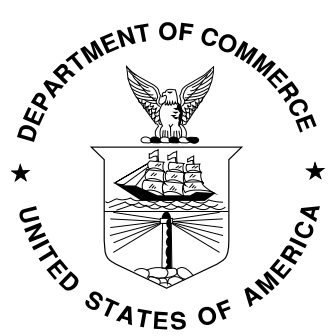

U.S. Department of Commerce Rebecca Blank, Acting Secretary

National Institute of Standards and Technology Patrick D. Gallagher, Under Secretary of Commerce for Standards and Technology and Director 


\section{EXECUTIVE SUMMARY}

Federal, state, and local first responders who work with explosives and respond to improvised explosive device (IED) attacks rely on relevant documentary standards to make their jobs safer. ${ }^{1}$ Per the International Organization for Standardization (ISO)/International Electrotechnical Commission (IEC) Guide 2:2004, there are eight common types of documentary standards: basic standards, terminology standards, testing standards, product standards, process standards, service standards, interface standards, and standards on data to be provided. ${ }^{2}$ Explosives documentary standards that span many of these categories are available (for a cost), but as of September 2012, no explosives standards have been adopted by the U.S. Department of Homeland Security (DHS). ${ }^{3}$

The DHS standards adoption process identifies appropriate and effective national standards that assist federal, state, and local equipment procurement processes, response, training development, and program coordination. Standards adoption assists with the following

- Encouraging and/or mandating that equipment purchased with federal dollars is certified to adopted standards (with exceptions noted when they exist);

- Achieving equipment interoperability;

- Developing training, exercise, and prevention programs;

- Harmonizing homeland security strategies, sharpening operational effectiveness, and maximizing efficiency within DHS and the federal government; and

- Encouraging uniform equipment purchases throughout the federal government based on informed input. ${ }^{4}$

From September 2011 to September 2012, the National Institute of Standards and Technology (NIST) Law Enforcement Standards Office (OLES), sponsored by the DHS Science and Technology Directorate (S\&T) Explosives Division, collected recommendations for the adoption and/or development of explosives standards by DHS and identified explosives standards gaps. NIST OLES named this effort the Explosives Standards Forum (ESF).

\footnotetext{
${ }^{1}$ Per NISTIR 7614, there are two types of standards: physical measurement and documentary. This effort focuses on documentary standards. (http://gsi.nist.gov/global/docs/pubs/NISTIR_7614.pdf)

${ }^{2}$ See http://www.iso.org/iso/catalogue detail?csnumber $=39976$ for more information.

${ }^{3}$ See https://www.rkb.us/contentdetail.cfm?content $\mathrm{id}=67919$ for a full list of adopted standards to date.

${ }^{4}$ See Explosives Standards Working Group (ESWG) documents and the Adoption of DHS National Standards: https://www.dhs.gov/xlibrary/assets/foia/mgmt directive 106001 adoption of department of homeland secur ity dhs national standards.pdf.
} 
The ESF

- Identified stakeholders in the explosives community, including

- Numerous federal agencies;

- State and local responders (primarily represented by the National Bomb Squad Commander Advisory Board [NBSCAB]); and

- Other subject-matter experts;

- Utilized stakeholder input to create a list of existing standards;

- Pared down the list and evaluated selected standards for DHS adoption;

- Analyzed standards gaps; and

- Produced a report detailing the final recommendations.

On behalf of the federal, state, and local responder community, the ESF is recommending the standards listed in Table 1 for DHS adoption. This recommendation is based on the collected narrative of federal, state, and local stakeholders; the scores collected through a controlled Decision Analysis and Resolution (DAR) process, which is based on the Capability Maturity Model Integration (CMMI) process improvement model; ${ }^{5}$ and additional subject-matter expert analysis.

Table 1. Standards Recommended for DHS Adoption

\begin{tabular}{|c|c|}
\hline Number & Title \\
\hline NIJ Standard-0117.0 & Public Safety Bomb Suit Standard \\
\hline ASTM F792-08 & $\begin{array}{l}\text { Standard Practice for Evaluating the Imaging Performance of Security } \\
\text { X-Ray Systems }\end{array}$ \\
\hline NIJ Standard-0603.01 & Portable X-Ray Systems for Use in Bomb Identification \\
\hline ANSI N42.44, 2008 & $\begin{array}{l}\text { American National Standard for the Performance of Checkpoint Cabinet } \\
\text { X-Ray Imaging Security Systems }\end{array}$ \\
\hline \multicolumn{2}{|l|}{ ASTM Series for Robotsa } \\
\hline ASTM E2801-11 & $\begin{array}{l}\text { Standard Test Method for Evaluating Emergency Response Robot } \\
\text { Capabilities: Mobility: Confined Area Obstacles: Gaps }\end{array}$ \\
\hline ASTM E2802-11 & $\begin{array}{l}\text { Standard Test Method for Evaluating Emergency Response Robot } \\
\text { Capabilities: Mobility: Confined Area Obstacles: Hurdles }\end{array}$ \\
\hline ASTM E2803-11 & $\begin{array}{l}\text { Standard Test Method for Evaluating Emergency Response Robot } \\
\text { Capabilities: Mobility: Confined Area Obstacles: Inclined Planes }\end{array}$ \\
\hline
\end{tabular}

${ }^{5}$ The DAR process (based on the CMMI model developed by the CMMI Institute, powered by Carnegie Mellon, www.cmmiinstitute.com) is a formalized decision-making process whereas decision criteria are developed, evaluated, and agreed upon at the beginning of a project. 


\begin{tabular}{|l|l|}
\hline ASTM E2804-11 & $\begin{array}{l}\text { Standard Test Method for Evaluating Emergency Response Robot } \\
\text { Capabilities: Mobility: Confined Area Obstacles: Stairs/Landings }\end{array}$ \\
\hline ASTM E2826-11 & $\begin{array}{l}\text { Standard Test Method for Evaluating Emergency Response Robot } \\
\text { Capabilities: Mobility: Confined Area Terrains: Continuous Pitch/Roll } \\
\text { Ramps }\end{array}$ \\
\hline ASTM E2827-11 & $\begin{array}{l}\text { Standard Test Method for Evaluating Emergency Response Robot } \\
\text { Capabilities: Mobility: Confined Area Terrains: Crossing Pitch/Roll Ramps }\end{array}$ \\
\hline ASTM E2828-11 & $\begin{array}{l}\text { Standard Test Method for Evaluating Emergency Response Robot } \\
\text { Capabilities: Mobility: Confined Area Terrains: Symmetric Stepfields }\end{array}$ \\
\hline ASTM E2829-11 & $\begin{array}{l}\text { Standard Test Method for Evaluating Emergency Response Robot } \\
\text { Capabilities: Mobility: Maneuvering Tasks: Sustained Speed }\end{array}$ \\
\hline ASTM E2830-11 & $\begin{array}{l}\text { Standard Test Method for Evaluating the Mobility Capabilities of } \\
\text { Emergency Response Robots Using Towing Tasks: Grasped Sleds }\end{array}$ \\
\hline ASTM Series for Blast Resistant Trash Receptaclesa \\
\hline ASTM E2639-12 & Standard Test Method for Blast Resistance of Trash Receptacles \\
\hline ASTM E2740-12 & $\begin{array}{l}\text { Standard Specification for Trash Receptacles Subjected to Blast } \\
\text { Resistance Testing }\end{array}$ \\
\hline ASTM E2831M-11 & $\begin{array}{l}\text { Standard Guide for Deployment of Blast Resistant Trash Receptacles in } \\
\text { Crowded Places }\end{array}$ \\
\hline
\end{tabular}

a These have been bundled for analysis as one standard as they are complementary components regarding one technology or knowledge area.

State and local ESF stakeholders also highly ranked/recommended the National Guidelines for Bomb Technicians; however, the ESF at large is not recommending it for adoption at this time due to its law enforcement sensitive classification.

The ESF has also identified the following standards gaps.

- Blasting Equipment. Participants discussed the variability in the performance of hand-held firing units on the market today. These are critical pieces of equipment used by bomb squads to detonate counter charges to defeat explosive devices. The participants agreed that the standard should specifically address energy output, disposal, and ruggedness, especially against falls and water. (Any research or standards development activity related to this gap should reference the Mine Safety and Health Administration's [MSHA] materials and standards on this topic, which includes 30 Code of Federal Regulations [CFR] 75.0-1 Subpart N.)

- Homemade Explosives/Continuing Education. Participants recognized a need for homemade explosives (HME) training standards/courses based on roles, including bomb squads, operations, specialists, explosives workers, and ordnance workers. 
- X-Ray Technology. Participants stated that x-ray standards should be developed or modified to account for new technology, including back scatter, dual energy, and millimeter wave.

- Robots and Interoperability. Participants were encouraged by the development of robot test standards and methods. However, they thought that there was a clear need for robot performance standards. In addition, consideration should be given to the development of standards to address robot interoperability and how robots communicate with one another and the bomb squads to work as a team.

- Communications. Standards for electromagnetic communications are not available outside the U.S. Department of Defense (DoD). Participants stated that an Explosive Ordnance Disposal (EOD) communications standard should be considered. The standard would address inter-bomb squad communications, communications between the bomb squad and other responders, and robot/sensor communications. In addition, the standard should address the security of information and intrinsic safety to prevent accidental detonation of an explosive device.

- Canine Teams Explosives Training. Participants noted that standards have yet to account for canine explosives detection activities. Test methods for canines are also necessary, and consideration should be given to the human-animal team. Any canine standard should also encompass incident mitigation once the canine has completed its task. Participants agreed that training standards for canine teams are paramount.

- Explosive Breaching. There are currently courses on explosive breaching, but there are no accreditation requirements for breaching training. Participants thought that standards for explosive breaching tools and training should be considered.

- Military Ordnance. State and local bomb squads are encountering an increasing amount of military ordnance in the U.S. Due to varying processes and procedures for incidents involving recovery of military ordnance. The participants indicated that standards addressing military ordnance response should be implemented.

- Explosive Containment Vessels and Total Containment Vessels (TCV). Fully enclosed TCVs were originally designed to contain an explosion but have evolved to include containment of toxic gases and biological or chemical agents. Manufacturers 
make claims that the vessels can contain repeated explosions and toxic materials, but no standard or testing exists to determine if these claims are true.

- Development of a Program to Use DHS-NIST-ASTM International Standard Test Methods for Response Robots (E54.08.01). NBSCAB recommended that E54.08.01 be used as a way to self-train and self-evaluate robot operator proficiency compared to "expert" operator performance captured during the standardization process.

- Portable Hand-Held Shields/Ballistic Shield Protection. A standard should be developed for portable hand-held shields carried by special weapons and tactics (SWAT) bomb technicians to protect against fragmentation and blast/shrapnel. This standard could be developed leveraging the work being performed by the National Institute of Justice (NIJ) at the University of Denver. (A representative from the Bureau of Alcohol, Tobacco, Firearms and Explosives [ATF] strongly cautioned that this concept should be analyzed and determined safe before developing a standard.)

This report details the activities of the ESF from September 2011 to September 2012 and includes a detailed approach, documentation of all findings, and final recommendations. 


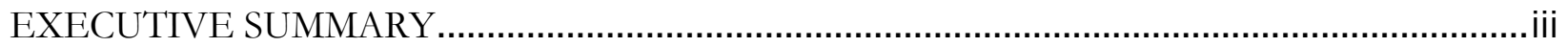

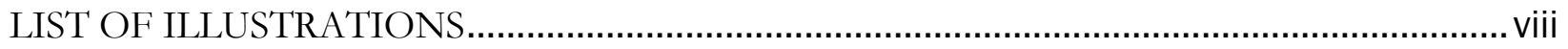

LIST OF TABLES ......................................................................................................... vii

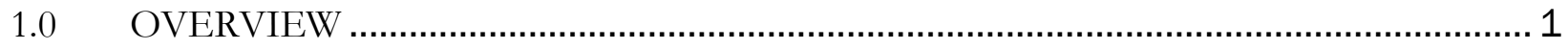

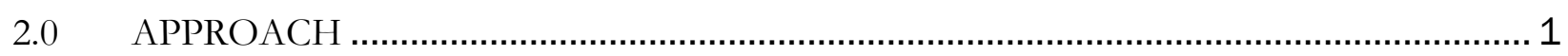

2.1 Identification of Stakeholders .............................................................................. 3

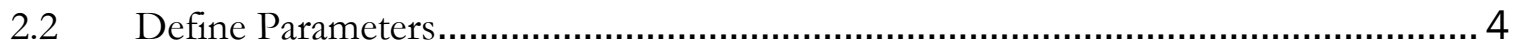

2.3 Research and Identification of Existing Standards .............................................. 4

2.4 Down-Selection of Standards for Evaluation .................................................... 5

2.5 Conduct Federal Stakeholder Focus Groups ..................................................... 7

2.6 Solicit State and Local Input at NBSCAB Meetings........................................... 8

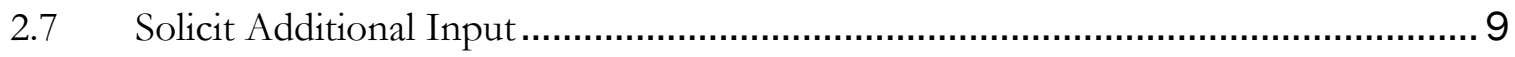

2.8 Conduct Final Analysis and Produce Scores ....................................................... 9

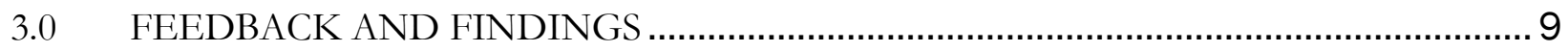

3.1 Input on Existing Standards for DHS Adoption ........................................... 9

3.1.2 Federal Focus Group Input on Existing Standards for DHS Adoption ........ 9

3.1.3 NBSCAB Input on Existing Standards for DHS Adoption .......................11

3.1.4 Additional Input.......................................................................... 12

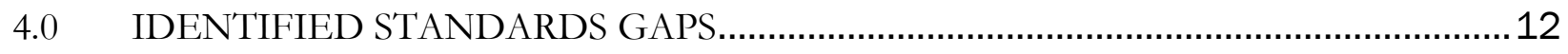

4.1 Federal Focus Group-Identified Standards Gaps............................................... 12

4.2 NBSCAB-Identified Standards Gaps................................................................. 13

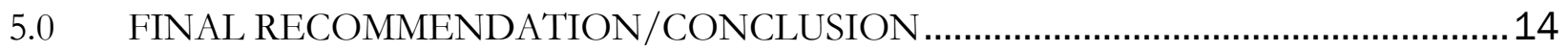

APPENDIX A ACRONYMS/ABBREVIATIONS

APPENDIX B LIST OF IDENTIFIED EXISTING STANDARDS TO DATE

APPENDIX C STANDARDS ANALYZED FOR DHS ADOPTION 


\section{LIST OF ILLUSTRATIONS}

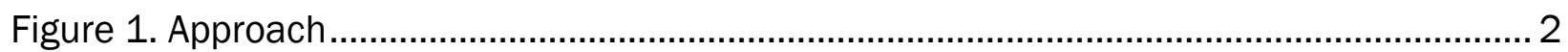

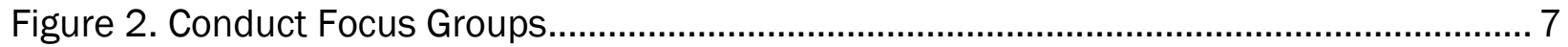

\section{LIST OF TABLES}

Table 1. Standards Recommended for DHS Adoption ...........................................................ii

Table 2. Sources of Existing Standards............................................................................... 5

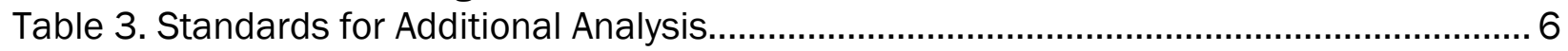

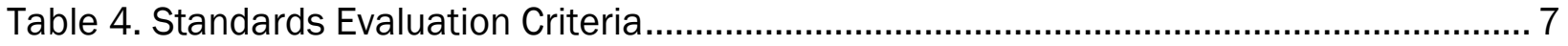

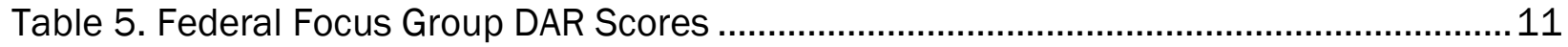

Table 6: Standards Recommended for DHS Adoption ....................................................... 14 


\subsection{OVERVIEW}

The National Institute of Standards and Technology (NIST) promotes U.S. innovation and industrial competitiveness by advancing measurement science, standards, and technology in ways that enhance economic security and improve our quality of life. Within NIST, the Law Enforcement Standards Office (OLES) directs programs and provides technical advice in a number of areas including criminal justice, public safety, forensic science, interoperable communications, emergency response, and counterterrorism. From September 2011 to August 2012, NIST OLES, sponsored by the Department of Homeland Security Science and Technology Directorate's (DHS S\&T) Explosives Division, collected recommendations for the adoption and/or development of explosives standards by the U.S. Department of Homeland Security (DHS) and identified explosives standards gaps. This effort is referred to throughout this report as the Explosives Standards Forum (ESF).

The following sections will describe the ESF's approach, findings, and recommendations.

\subsection{APPROACH}

The ESF was executed as a collaborative effort between federal, state, and local stakeholders with a common goal to produce a list of recommended standards for DHS adoption and a list of identified standards gaps. The process was purposely inclusive and all input was considered in the final analysis phase. The major steps in the approach are discussed in Sections 2.1 through 2.8. Figure 1 illustrates the approach that the ESF followed. 
ESF Process for Identifying Existing Standards for Adoption

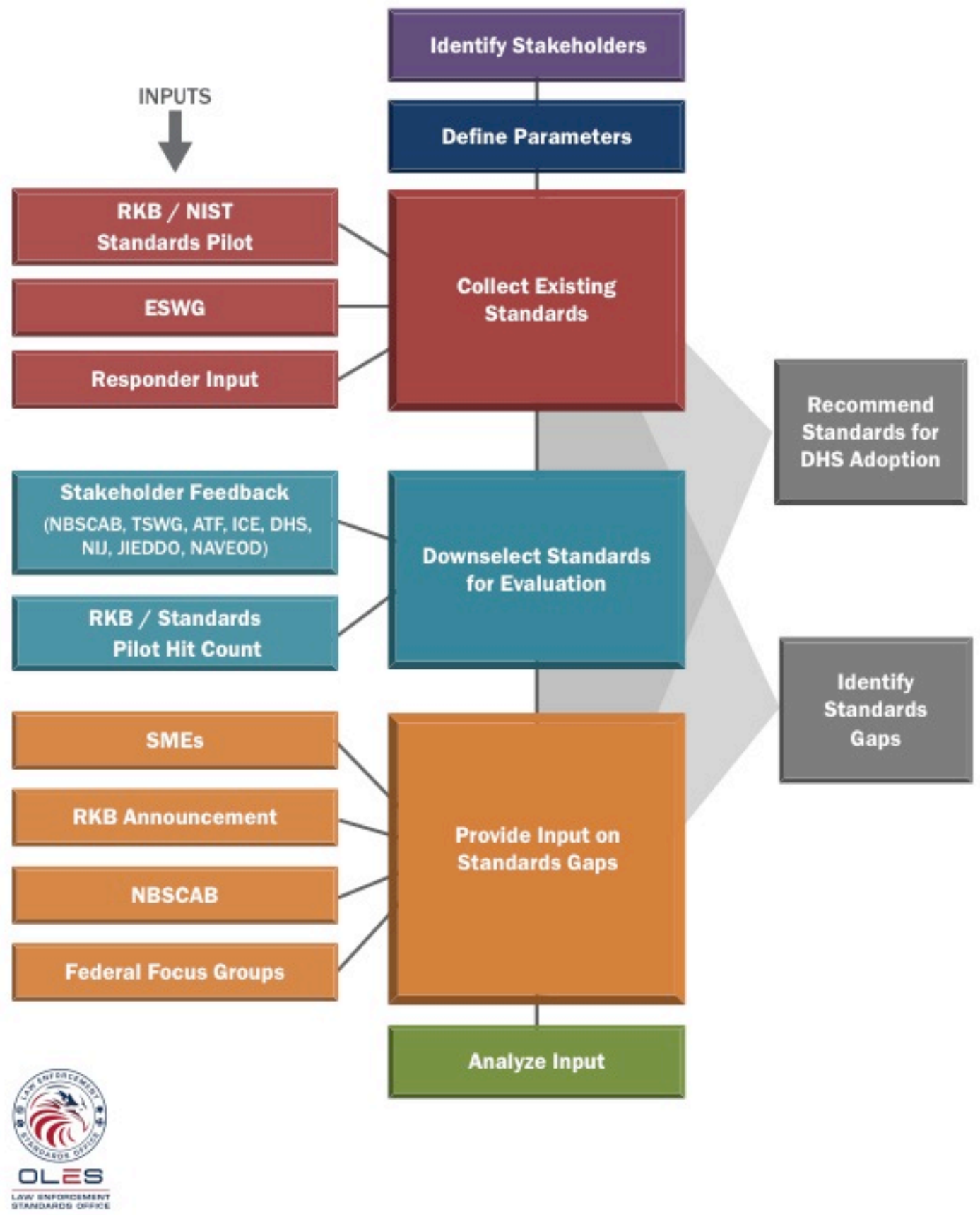

Figure 1. Approach 


\subsection{Identific ation of Stakeholders}

NIST OLES identified stakeholders in the explosives community at the federal, state, and local levels. Maximum participation and feedback was solicited at all levels of the process from individuals representing the following agencies:

1. Federal representation

a. Department of Defense (DoD)

i. Combating Terrorism Technical Support Office (CTTSO) Technical Support Working Group (TSWG)

ii. Joint Improvised Explosive Device (IED) Defeat Organization (JIEDDO)

iii. Naval Explosive Ordnance Disposal Technology Division (NAVEODTECHDIV)

b. U.S. Department of Treasury

i. Bureau of Alcohol, Tobacco, Firearms and Explosives (ATF)

c. DHS

i. Immigration and Customs Enforcement (ICE)

ii. Federal Protective Services (FPS)

iii. DHS S\&T Explosives Division

iv. Office of Bombing Prevention (OBP)

d. U.S. Department of Justice (DOJ)

i. National Institute of Justice (NIJ), Office of Science and Technology, Operational Technologies Division

ii. Federal Bureau of Investigation (FBI), Hazardous Device School (HDS) 
e. U.S. Department of Commerce

i. NIST OLES

ii. NIST Material Measurement Laboratory (MML)

2. State and local representation

a. National Bomb Squad Commanders Advisory Board (NBSCAB) (feedback by quorum)

b. Responder Knowledge Base (RKB) community (http://www.rkb.us/)

3. Explosives Standards Working Group (ESWG $)^{6}$

\subsection{Define Parameters}

The ESF focused solely on explosives documentary standards (and did not address physical standards) for this effort. The ESF set forth the goals of recommending standards for DHS adoption and of recording all standards gaps put forth by stakeholders.

\subsection{Research and Identification of Existing Standards}

NIST OLES identified 34 existing published explosives standards, which included basic standards, terminology standards, testing standards, product standards, process standards, and service standards. Each source listed in Table 1 provided input. For the full list of identified existing standards, see Appendix B.

\footnotetext{
${ }^{6}$ The ESWG commenced in 2008 with the goal of providing "all DHS agencies with a forum/platform for collaboration and information exchange with national and international standards development bodies, other federal agencies, state and local government agencies and non-government entities on explosives related standards and conformity assessment measures." The ESWG produced a number of materials and recommendations before it concluded in 2010, and all produced materials were used as inputs to the ESF.
} 


\section{Table 2. Sources of Existing Standards}

\begin{tabular}{|l|l|}
\hline \multicolumn{2}{|c|}{ Source } \\
\hline Fe09 ESWG & $\begin{array}{l}\text { The 2009 ESWG plans, briefings, and documents were evaluated for input } \\
\text { into this ESF process. }\end{array}$ \\
\hline NBSCAB Feedback & The federal stakeholders identified a list of existing standards. \\
\hline RKB & $\begin{array}{l}\text { NBSCAB members provided an initial set of standards for consideration } \\
\text { during their November 2011 meeting. }\end{array}$ \\
\hline NIST OLES Standards Pilot & NIST OLES analyzed top-viewed explosives standards for inclusion. \\
\hline $\begin{array}{l}\text { An analysis was conducted on findings from the NIST OLES Standards } \\
\text { Pilot for explosives standards applicability based on document requests } \\
\text { or user feedback. These findings determined key equipment or training } \\
\text { issues that the responder community has a strong interest in tracking and } \\
\text { necessitated the inclusion of several of the radiographic standards on the } \\
\text { evaluation list. }\end{array}$ \\
\hline
\end{tabular}

\subsection{Down-Selection of Standards for Evaluation}

The ESF used stakeholder input (federal, state, and local) and the ranked popularity of the standards on websites such as the RKB and the Standards Pilot platform to pare down the list to a more manageable number of standards for closer evaluation. The downscaled list of 21 standards included those that stakeholders deemed most relevant to the explosives community. The list of standards deemed most relevant for further evaluation is in Table 3. Summaries of these standards are included in Appendix C.

\footnotetext{
${ }^{7}$ See http://www.nist.gov/manuscript-publication-search.cfm?pub id=910380.
} 


\title{
Table 3. Standards for Additional Analysis
}

\author{
Standard Number and Title
}

NIJ Standard-0603.01, Portable X-Ray Systems for Use in Bomb Identification

ASTM Series for Robotsa

- ASTM E2801-11, Standard Test Method for Evaluating Emergency Response Robot Capabilities: Mobility: Confined Area Obstacles: Gaps

- ASTM E2802-11, Standard Test Method for Evaluating Emergency Response Robot Capabilities: Mobility: Confined Area Obstacles: Hurdles

- ASTM E2803-11, Standard Test Method for Evaluating Emergency Response Robot Capabilities: Mobility: Confined Area Obstacles: Inclined Planes

- ASTM E2804-11, Standard Test Method for Evaluating Emergency Response Robot Capabilities: Mobility: Confined Area Obstacles: Stairs/Landings

- ASTM E2826-11, Standard Test Method for Evaluating Emergency Response Robot Capabilities: Mobility: Confined Area Terrains: Continuous Pitch/Roll Ramps

- ASTM E2827-11, Standard Test Method for Evaluating Emergency Response Robot Capabilities: Mobility: Confined Area Terrains: Crossing Pitch/Roll Ramps

- ASTM E2828-11, Standard Test Method for Evaluating Emergency Response Robot Capabilities: Mobility: Confined Area Terrains: Symmetric Stepfields

- ASTM E2829-11, Standard Test Method for Evaluating Emergency Response Robot Capabilities: Mobility: Maneuvering Tasks: Sustained Speed

- ASTM E2830-11, Standard Test Method for Evaluating the Mobility Capabilities of Emergency Response Robots Using Towing Tasks: Grasped Sleds

ASTM E2520-07, Standard Practice for Verifying Minimum Acceptable Performance of Trace Explosive Detectors

ASTM Series for Blast Resistant Trash Receptacles ${ }^{a}$

- ASTM E2639-12, Standard Test Method for Blast Resistance of Trash Receptacles

- ASTM E2740-12, Standard Specification for Trash Receptacles Subjected to Blast Resistance Testing

- ASTM E2831M-11, Standard Guide for Deployment of Blast Resistant Trash Receptacles in Crowded Places

National Guidelines for Bomb Technicians 2012

ASTM F792-08, Standard Practice for Evaluating the Imaging Performance of Security X-Ray Systems

NIJ Standard-0117.00, Public Safety Bomb Suit Standard

ANSI N42.47-2010, American National Standard for Measuring the Imaging Performance of X-Ray and Gamma-Ray Systems for Security Screening of Humans

ANSI N42.44-2008, American National Standard for the Performance of Checkpoint Cabinet X-Ray Imaging Security Systems

ANSI N42.45-2011, American National Standard for Evaluating the Image Quality of X-ray Computed Tomography (CT) Security-Screening Systems

ANSI N42.46-2008, American National Standard for the Determination of the Imaging Performance of X-Ray and Gamma-Ray Systems for Cargo and Vehicle Security Screening

a These have been bundled for analysis as one standard as they are complementary components regarding one technology or knowledge area. 


\subsection{Conduct Federal Stakeholder Foc us Groups}

The ESF solicited input on 21 standards during two separate federal focus groups (in Washington, DC, and Gaithersburg, MD). The focus groups provided feedback and ratings for each standard against established evaluation criteria utilizing a Decision Analysis and Resolution (DAR) process, based on the Capability Maturity Model Integration (CMMI) model. ${ }^{8}$ Prior to the first focus group, specific evaluation criteria were developed based on input from the federal focus group participants and guidance found in DHS Management Directive 10600.1, Adoption of Department of Homeland Security (DHS) National Standards. At the focus group, attendees reviewed and approved the criteria and assigned a specific weight to each related to level of importance. Once the criteria and weights were finalized, attendees rated each standard against the criteria. The same criteria and weightings were used for all federal participant input during the first and second focus groups (see Figure 2). These criteria are listed in Table 4.

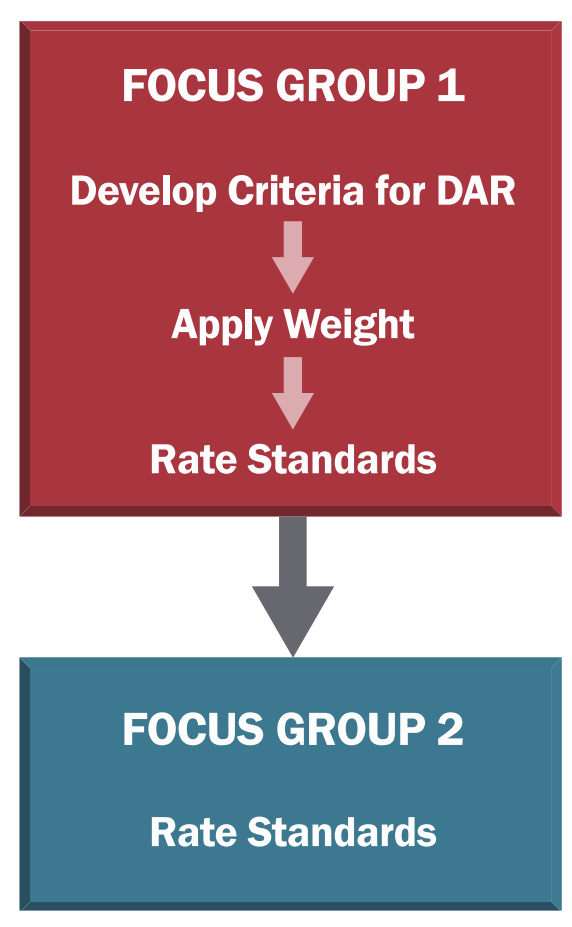

Figure 2. Conduct Focus

Table 4. Standards Evaluation Criteria

\begin{tabular}{|c|c|c|}
\hline Weight & Criteria & Criteria Considerations \\
\hline $20 \%$ & $\begin{array}{l}\text { Was the standard updated within the } \\
\text { last } 5 \text { years? }\end{array}$ & - Is there a process to update the standard? \\
\hline $25 \%$ & $\begin{array}{l}\text { Is the standard relevant to state/local } \\
\text { responders and industry? }\end{array}$ & $\begin{array}{l}\text { Does the standard promote and develop best } \\
\text { practices and operations? } \\
\text { Does it provide guidance in the purchase of } \\
\text { effective, safe, quality, necessary, and } \\
\text { interoperable equipment and promote confidence } \\
\text { in that equipment? } \\
\text { Does it define minimum performance } \\
\text { levels/requirements, test methods, specifications, } \\
\text { and operation procedures? }\end{array}$ \\
\hline
\end{tabular}

\footnotetext{
8 The DAR process (based on the CMMI model developed by the CMMI Institute, powered by Carnegie Mellon, www.cmmiinstitute.com) is a formalized decision-making process whereas decision criteria are developed, evaluated, and agreed upon at the beginning of a project.
} 


\begin{tabular}{|c|c|c|}
\hline $15 \%$ & $\begin{array}{l}\text { Is the standard relevant to the federal } \\
\text { response community? }\end{array}$ & $\begin{array}{l}\text { - Does the standard assist with the Federal Grants } \\
\text { Program? } \\
\text { Does it assist in collaboration and information } \\
\text { exchange between the federal and } \\
\text { state/local/tribal governments and non- } \\
\text { government entities? } \\
\text { Does it promote standardized decisions/operations } \\
\text { within DHS by developing clear and unambiguous } \\
\text { requirements and performance objectives when } \\
\text { assisting with explosives related programs? }\end{array}$ \\
\hline $20 \%$ & $\begin{array}{l}\text { Is the standard authored/developed by } \\
\text { a reputable and recognized } \\
\text { organization using open and } \\
\text { transparent procedures? }\end{array}$ & $\begin{array}{l}\text { - Is the standard based on data from reputable } \\
\text { institutions? } \\
\text { - Is the document based on a consensus procedure? } \\
\text { Were members of the responder community } \\
\text { involved in the development of the standard? }\end{array}$ \\
\hline $15 \%$ & $\begin{array}{l}\text { Does the standard maximize } \\
\text { responder effectiveness and not create } \\
\text { any unnecessary burdens? }\end{array}$ & $\begin{array}{l}\text { Does the standard present clear benefits for safety } \\
\text { or performance? } \\
\text { Does it present a reasonable ratio of effectiveness } \\
\text { to efficiency? }\end{array}$ \\
\hline $5 \%$ & Is the standard easily accessible? & $\begin{array}{l}\text { - Is there a cost associated with obtaining the } \\
\text { standard? }\end{array}$ \\
\hline
\end{tabular}

The DAR was based on a 100-point scoring scale. The final acceptance criteria received a weighted percentage to total 100 percent, and each standard was scored on a scale of 1 to 5 for its applicability to each of the acceptance criteria. The DAR process accounts for scoring from multiple stakeholders, and the resulting calculations provide an averaged, weighted score for each standard.

\subsection{Solicit State and Local Input at NBSCAB Meetings}

State and local input was solicited through the National Bomb Squad Commanders Advisory Board (NBSCAB). The NBSCAB's mission is "to act in a leadership role for the bomb squad community, providing guidance and advice on important issues." The NBSCAB focuses on initiatives to improve bomb squad tactics, techniques, procedures, training and equipment. Further, the NBSCAB sets guidelines and standards for the bomb squad community through its role as elected representatives for state and local bomb squads. In addition, numerous federal agencies involved in issues related to state and local bomb squads regularly attend and contribute at the NBSCAB meetings. ${ }^{9}$

\footnotetext{
${ }^{9}$ See http://nbscab.org/NBSCAB/nbscab ex.php for more information.
} 
During the commencement of the ESF, DHS designated the NBSCAB to represent the responder community. The NBSCAB, per its by-laws, provided collective input by quorum to the ESF. The input focused mainly on the specific needs of bomb technicians (local, state, and federal). During the ESF process, NBSCAB reviewed, approved, and recommended standards to be considered for adoption and identified standards to be developed.

\subsection{Solicit Additional Input}

NIST posted a question on the RKB website (http://www.rkb.us/) to solicit additional input from federal government users.

\subsection{Conduct Final Analysis and Produce Scores}

The DAR scores were not solely relied upon for final recommendations. Collected narrative was considered as valuable in determining the final recommendation.

The final phase, per the established methodology, included reviewing all inputs from the various stakeholders, producing scores, and determining final suitability for adoption.

\subsection{FEEDBACK AND FINDINGS}

\subsection{Input on Existing Standards for DHS Adoption}

This section details input from all solicited sources as related to existing explosives standards recommendations.

\subsubsection{Federal Focus Group Input on Existing Standards for DHS Adoption}

Both focus groups talked in depth about the existing explosives standards and related topics. Comments were collected without attribution and paraphrased as follows:

- The federal focus group participants favored basic, product, or process standards for DHS adoption. While testing and service standards are valuable in the federal, state, and local responder community, the participants thought that performance standards were more desirable and useful. 
- Participants agreed that standards can quickly become expensive for a bomb squad. A federal focus group attendee pointed out that standards in the ASTM Series for Robots are $\$ 40.00$ each, and the whole series totals $\$ 360.00$. Participants were unaware of efforts by DHS to provide some standards at no cost to responders and generally thought that most responders were also unaware of this service.

- Participants indicated that they had found most standards related to explosives range from approximately $\$ 10.00$ to $\$ 100.00$. They agreed that standards for responders should be free, especially standards that were developed and published utilizing federal dollars. Participants noted that some federal agencies are not able to purchase standards in bulk and thus are not able to take advantage of economies of scale in buying.

- Participants discussed the disconnect between the research and development community and the standards community. For example, a technology may be created or improved, but a standard may not be available to support the new technology. This leaves the responders and researchers unable to evaluate the technology's performance and applicability to the current needs.

- One of the general observations by the participants was that bomb squads are moving toward using teams of robots for incidents. Participants agreed that the major standards issue with robots is communication between the robot and operator, between robots, and between the robot and other sensors.

- Participants stated that the Mine Safety and Health Administration (MSHA) had produced several relevant standards and agreed that these should be readily available to bomb squads.

Standards-specific feedback includes:

- ASTM E2520-07 does not address current threats, but the standard is in the process of being revised.

- NIJ 0603.01 does not account for back scatter or dual energy devices; as a result, the standard does not address all $\mathrm{x}$-ray technologies. 
- The National Guidelines for Bomb Technicians falls in the category of a process standard and is a valued resource; however, it is classified as law enforcement sensitive, making it more difficult to obtain and recommend for DHS adoption.

Each federal focus group attendee rated the aforementioned standards per the evaluation criteria. Ratings were added up to produce a score for each standard. Ratings from the two groups were combined. Scores that resulted from the DAR process are shown below, in Table 4.

Table 5. Federal Focus Group DAR Scores

\begin{tabular}{|l|l|}
\hline \multicolumn{2}{|c|}{ Score } \\
\hline $87 \%$ & NIJ Standard-0117.00, Public Safety Bomb Suit Standard \\
\hline $84 \%$ & ASTM Series for Blast Resistant Trash Receptacles \\
\hline $83 \%$ & $\begin{array}{l}\text { ASTM F792-08, Standard Practice for Evaluating the Imaging Performance of Security X-Ray } \\
\text { Systems }\end{array}$ \\
\hline $82 \%$ & NIJ Standard-0603.01, Portable X-Ray Systems for Use in Bomb Identification \\
\hline $77 \%$ & $\begin{array}{l}\text { ANSI N42.44-2008, American National Standard for the Performance of Checkpoint Cabinet } \\
\text { X-Ray Imaging Security Systems }\end{array}$ \\
\hline $76 \%$ & National Guidelines for Bomb Technicians 2012 \\
\hline $75 \%$ & ASTM Series for Robots \\
\hline $64 \%$ & $\begin{array}{l}\text { ANSI N42.45-2011, American National Standard for Evaluating the Image Quality of X-Ray } \\
\text { Computed Tomography (CT) Security-Screening Systems }\end{array}$ \\
\hline $62 \%$ & $\begin{array}{l}\text { ANSI N42.46-2008, American National Standard for Determination of the Imaging Performance } \\
\text { of X-Ray and Gamma-Ray Systems for Cargo and Vehicle Security Screening }\end{array}$ \\
\hline $61 \%$ & $\begin{array}{l}\text { ANSI N42.47-2010, American National Standard for Measuring the Imaging Performance of } \\
\text { X-ray and Gamma-ray Systems for Security Screening of Humans }\end{array}$ \\
\hline $54 \%$ & $\begin{array}{l}\text { ASTM E2520-07, Standard Practice for Verifying Minimum Acceptable Performance of Trace } \\
\text { Explosive Detectors }\end{array}$ \\
\hline
\end{tabular}

\subsubsection{NBSCAB Input on Existing Standards for DHS Adoption}

After discussion, NBSCAB members recommended that DHS adopt the following standards:

1) NIJ Standard-0603.01, Portable X-Ray Systems for Use in Bomb Identification

2) National Guidelines for Bomb Technicians 2012

3) NIJ Standard-0117.00, Public Safety Bomb Suit Standard

4) ASTM Series for Robots 
The above standards are up to date, are relevant to the community at large, and maximize responder effectiveness. NBSCAB posed no objection to adoption of the remaining presented standards but opted not to specifically recommend them for adoption because they fall outside NBSCAB's main area of responsibility.

\subsubsection{Additional Input}

The ESF received no additional input from the federal members of the RKB in regards to explosives standards to adopt or standards gaps that needed to be addressed.

\subsection{IDENTIFIED STANDARDS GAPS}

\subsection{Federal Focus Group-Identified Standards Gaps}

Both federal focus groups discussed the need for improvements to existing or the establishment of new standards for the explosives community. The participants thought the following were the highest priority for consideration.

- Ballistic Shield Protection. Current standards do not account for ballistic shield protection for bomb squads. Standards specific to portable, hand-held shields for blast, shrapnel, and overpressure protection should be considered. (This gap was combined with the Portable Hand-Held Shields gap in the final recommendations).

- Blasting Equipment. Participants discussed the variability in the performance of hand-held firing units on the market today. These are critical pieces of equipment used by bomb squads to detonate counter charges to defeat explosive devices. The participants agreed that the standard should specifically address energy output, disposal, and ruggedness, especially against falls and water.

- Homemade Explosives/Continuing Education. Participants recognized a need for homemade explosives (HME) training standards/courses based on roles, including bomb squads, operations, specialists, explosives workers, and ordnance workers.

- X-Ray Technology. Participants stated that x-ray standards should be developed or modified to account for new technology including back scatter, dual energy, and millimeter wave. 
- Robots and Interoperability. Participants were encouraged by the development of robot test standards and methods. However, they thought there was a clear need for robot performance standards. In addition, consideration should be given to the development of standards to address robot interoperability and how robots communicate with one another and the bomb squads to work as a team.

- Communications. Standards for electromagnetic communication are not available outside DoD. Participants stated that an Explosive Ordnance Disposal (EOD) communications standard should be considered. The standard would address interbomb squad communications, communications between the bomb squad and other responders, and robot/sensor communications. In addition, the standard should address the security of information and intrinsic safety to prevent accidental detonation of an explosive device.

- Canine Teams Explosives Training. Participants noted that standards have yet to account for canine explosives detection activities. Test methods for canines are also necessary, and consideration should be given to the human-animal team. Any canine standards should also encompass incident mitigation once the canine has completed its task. Participants agreed that training standards for canine teams are paramount.

- Explosive Breaching. There are currently courses on explosive breaching, but there are no accreditation requirements for breaching training. Participants thought that standards for explosive breaching tools and training should be considered.

- Military Ordnance. State and local bomb squads are encountering an increasing amount of military ordnance in the U.S. Due to varying processes and procedures for incidents involving recovery of military ordnance, the participants indicated that standards addressing military ordnance response should be implemented.

\subsection{NBSCAB-Identified Standards Gaps}

NBSCAB recommended that standards or programs be developed related to the following explosives issues.

- Explosive Containment Vessels and Total Containment Vessels (TCV). Fully enclosed TCVs were originally designed to contain an explosion but have evolved to include containment of toxic gases and biological or chemical agents. Manufacturers 
make claims that the vessels can contain repeated explosions and toxic materials, but no standard or testing exists to determine if these claims are true.

- Development of a Program to Use DHS-NIST-ASTM International Standard Test Methods for Response Robots (E54.08.01). NBSCAB recommended that E54.08.01 be used as a way to self-train and self-evaluate robot operator proficiency compared to "expert" operator performance captured during the standardization process.

- Portable Hand-Held Shields. NBSCAB encourages the development of a standard for portable hand-held shields carried by special weapons and tactics (SWAT) bomb technicians to protect against blast/shrapnel. This standard could be developed by leveraging the work being performed by NIJ at the University of Denver.

\subsection{FINAL RECOMMENDATION/CONCLUSION}

The ESF compared and normalized input from various stakeholders using detailed narrative analysis and formal DAR scores and considered the purpose for DHS adoption. The ESF recommends the following standards for DHS adoption:

\section{Table 6: Standards Recommended for DHS Adoption}

\begin{tabular}{|l|l|}
\hline \multicolumn{1}{|c|}{ Number } & \multicolumn{1}{|c|}{ Title } \\
\hline NIJ Standard-0117.0 & Public Safety Bomb Suit Standard \\
\hline ASTM F792-08 & $\begin{array}{l}\text { Standard Practice for Evaluating the Imaging Performance of Security X-Ray } \\
\text { Systems }\end{array}$ \\
\hline NIJ Standard-0603.01 & Portable X-Ray Systems for Use in Bomb Identification \\
\hline ANSI N42.44, 2008 & $\begin{array}{l}\text { American National Standard for the Performance of Checkpoint Cabinet X-Ray } \\
\text { Imaging Security Systems }\end{array}$ \\
\hline ASTM Series for Robotsa & $\begin{array}{l}\text { Standard Test Method for Evaluating Emergency Response Robot Capabilities: } \\
\text { Mobility: Confined Area Obstacles: Gaps }\end{array}$ \\
\hline ASTM E2801-11 & $\begin{array}{l}\text { Standard Test Method for Evaluating Emergency Response Robot Capabilities: } \\
\text { Mobility: Confined Area Obstacles: Hurdles }\end{array}$ \\
\hline ASTM E2802-11 & $\begin{array}{l}\text { Standard Test Method for Evaluating Emergency Response Robot Capabilities: } \\
\text { Mobility: Confined Area Obstacles: Inclined Planes }\end{array}$ \\
\hline ASTM E2803-11 & $\begin{array}{l}\text { Standard Test Method for Evaluating Emergency Response Robot Capabilities: } \\
\text { Mobility: Confined Area Obstacles: Stairs/Landings }\end{array}$ \\
\hline ASTM E2804-11 & $\begin{array}{l}\text { Standard Test Method for Evaluating Emergency Response Robot Capabilities: } \\
\text { Mobility: Confined Area Terrains: Continuous Pitch/Roll Ramps }\end{array}$ \\
\hline ASTM E2826-11 &
\end{tabular}




\begin{tabular}{|l|l|}
\hline ASTM E2827-11 & $\begin{array}{l}\text { Standard Test Method for Evaluating Emergency Response Robot Capabilities: } \\
\text { Mobility: Confined Area Terrains: Crossing Pitch/Roll Ramps }\end{array}$ \\
\hline ASTM E2828-11 & $\begin{array}{l}\text { Standard Test Method for Evaluating Emergency Response Robot Capabilities: } \\
\text { Mobility: Confined Area Terrains: Symmetric Stepfields }\end{array}$ \\
\hline ASTM E2829-11 & $\begin{array}{l}\text { Standard Test Method for Evaluating Emergency Response Robot Capabilities: } \\
\text { Mobility: Maneuvering Tasks: Sustained Speed }\end{array}$ \\
\hline ASTM E2830-11 & $\begin{array}{l}\text { Standard Test Method for Evaluating the Mobility Capabilities of Emergency } \\
\text { Response Robots Using Towing Tasks: Grasped Sleds }\end{array}$ \\
\hline ASTM Series for Blast Resistant Trash Receptaclesa \\
\hline ASTM E2639-12 & Standard Test Method for Blast Resistance of Trash Receptacles \\
\hline ASTM E2740-12 & $\begin{array}{l}\text { Standard Specification for Trash Receptacles Subjected to Blast Resistance } \\
\text { Testing }\end{array}$ \\
\hline ASTM E2831M-11 & $\begin{array}{l}\text { Standard Guide for Deployment of Blast Resistant Trash Receptacles in Crowded } \\
\text { Places }\end{array}$ \\
\hline
\end{tabular}

a These have been bundled for analysis as one standard as they are complementary components regarding one technology or knowledge area.

These standards were all ranked higher than $70 \%$, and verbal narrative from the stakeholders supported the scores. The National Guidelines for Bomb Technicians was recommended by NBSCAB; however, it was not included due to its law enforcement sensitive classification.

The ESF also identified the following standards gaps.

- Blasting Equipment. Participants discussed the variability in the performance of hand-held firing units on the market today. These are critical pieces of equipment used by bomb squads to detonate counter charges to defeat explosive devices. The participants agreed that the standard should specifically address energy output, disposal, and ruggedness, especially against falls and water. (Any research or standards development activity related to this gap should reference the MSHA materials and standards on this topic, which includes 30 Code of Federal Regulation [CFR] 75.0-1 Subpart N).

- Homemade Explosives/Continuing Education. Participants recognized a need for homemade explosives (HME) training standards/courses based on roles, including bomb squads, operations, specialists, explosives workers, and ordnance workers.

- X-Ray Technology. Participants stated that x-ray standards should be developed or modified to account for new technology, including back scatter, dual energy, and millimeter wave. 
- Robots and Interoperability. Participants were encouraged by the development of robot test standards and methods. However, they thought there was a clear need for robot performance standards. In addition, consideration should be given to the development of standards to address robot interoperability and how robots communicate with one another and the bomb squads to work as a team.

- Communications. Standards for electromagnetic communication are not available outside DoD. Participants stated that an EOD communications standard should be considered. The standard would address inter-bomb squad team communications, communications between bomb squads and other responders, and robot/sensor communications. In addition, the standard should address the security of information and intrinsic safety to prevent accidental detonation of an explosive device.

- Canine Teams Explosives Training. Participants noted that standards have yet to account for canine mitigation activities. Test methods for canines are also necessary, and consideration should be given to the human-animal team. Any canine standards should also encompass incident mitigation once the canine has completed its task. Participants agreed that training standards for canine teams are paramount.

- Explosive Breaching. There are currently courses on explosive breaching, but there are no accreditation requirements for breaching training. Participants thought that standards for explosive breaching tools and training should be considered.

- Military Ordnance. State and local bomb squads are encountering an increasing amount of military ordnance in the U.S. Due to varying processes and procedures for incidents involving recovery of military ordnance, the participants indicated that standards addressing military ordnance response should be implemented.

- Explosive Containment Vessels and TCVs. Fully enclosed TCVs were originally designed to contain an explosion but have evolved to include containment of toxic gases and biological or chemical agents. Manufacturers make claims that the vessels can contain repeated explosions and toxic materials, but no standard or testing exists to determine if these claims are true.

- Development of a Program to Use DHS-NIST-ASTM International Standard Test Methods for Response Robots (E54.08.01). NBSCAB recommended that E54.08.01 be used as a way to self-train and self-evaluate robot operator proficiency 
compared to "expert" operator performance captured during the standardization process.

- Portable Hand-Held Shields/Ballistic Shield Protection. A standard should be developed for portable hand-held shields carried by SWAT bomb technicians to protect against fragmentation and blast/shrapnel. This standard could be developed by leveraging the work being performed by NIJ at the University of Denver. (A representative from the ATF strongly cautioned that this concept should be analyzed and determined safe before developing a standard.) 


\section{APPENDIX A}

\section{ACRONYMS/ABBREVIATIONS}




\section{APPENDIX A ACRONYMS/ABBREVIATIONS}

ANSI

ATF

BSR

CBRN

CFR

CMMI

CTTSO

DAR

DHS

DoD

DOJ

EOD

$\mathrm{ESF}$

ESWG

FBI

FPS

HDS

HME

ICE

IEC

IED

IEEE

ISO

JIEDDO
American National Standards Institute

Bureau of Alcohol, Tobacco, Firearms and Explosives

Board of Standards Review

Chemical, Biological, Radiological, Nuclear

Code of Federal Regulation

Capability Maturity Model Integration

Countering Terrorism Technical Support Office

Decision Analysis and Resolution

U.S. Department of Homeland Security

U.S. Department of Defense

U.S. Department of Justice

Explosive Ordnance Disposal

Explosives Standards Forum

Explosives Standards Working Group

Federal Bureau of Investigation

Federal Protective Services

Hazardous Device School

Homemade Explosives

Immigration and Customs Enforcement

International Electrotechnical Commission

Improvised Explosive Device

Institute of Electrical and Electronics Engineers

International Organization for Standardization

Joint Improvised Explosive Device Defeat Organization 
MSHA

MML

NAVEOD

NBSCAB

NIJ

NIST

OBP

OLES

$\mathrm{RKB}$

S\&T

SME

SOP

SWAT

TCV

TSWG

VBIED
Mine Safety and Health Administration

Material Measurement Laboratory

Naval Explosive Ordnance Disposal

National Bomb Squad Commander Advisory Board

National Institute of Justice

National Institute of Standards and Technology

Office of Bombing Prevention

Law Enforcement Standards Office

Responder Knowledge Base (http://www.rkb.us/)

Science and Technology

Subject Matter Expert

Standard Operating Procedures

Special Weapons and Tactics

Total Containment Vessel

Technical Support Working Group

Vehicle-Borne Improvised Explosive Device 
APPENDIX B

LIST OF IDENTIFIED EXISTING STANDARDS TO DATE 


\section{APPENDIX B \\ LIST OF IDENTIFIED EXISTING STANDARDS TO DATE}

\begin{tabular}{|c|c|c|}
\hline & Number & Title \\
\hline 1 & & National Guidelines for Bomb Technicians 2012 (Law Enforcement Sensitive) \\
\hline 2 & & National Strategic Plan for U.S. Bomb Squads \\
\hline 3 & & ATF Vehicle Bomb Explosion Hazard and Evacuation Distance Tables \\
\hline 4 & & ATF Federal Explosives Law and Regulations \\
\hline 5 & & ATF Explosives Tracing Pocket Guide (Law Enforcement Sensitive) \\
\hline 6 & & ATF Detonator Recognition and Identification Guide \\
\hline 7 & 2010-1-A & FBI Bomb Data Center Special Bulletin: Model for Bomb Squad SOPs \\
\hline 8 & & Weapons Technical Intelligence Improvised Explosive Device Lexicon \\
\hline 9 & NIJ Standard-0603.01 & Portable X-Ray Systems for Use in Bomb Identification \\
\hline 10 & NIJ Standard-0117.00 & Public Safety Bomb Suit Standard \\
\hline 11 & NIJ Standard-0116.00 & CBRN Protective Ensemble Standard for Law Enforcement \\
\hline 12 & ANSI N42.44-2008 & $\begin{array}{l}\text { American National Standard for the Performance of Checkpoint Cabinet X-Ray } \\
\text { Imaging Security Systems }\end{array}$ \\
\hline 13 & ANSI N42.45-2011 & $\begin{array}{l}\text { American National Standard for Evaluating the Image Quality of X-ray Computed } \\
\text { Tomography (CT) Security-Screening Systems }\end{array}$ \\
\hline 14 & ANSI N42.46-2008 & $\begin{array}{l}\text { American National Standard for Determination of the Imaging Performance of } \\
\text { X-Ray and Gamma-Ray Systems for Cargo and Vehicle Security Screening }\end{array}$ \\
\hline 15 & ANSI N42.47-2010 & $\begin{array}{l}\text { American National Standard for Measuring the Imaging Performance of X-ray and } \\
\text { Gamma-ray Systems for Security Screening of Humans }\end{array}$ \\
\hline 16 & ANSI/IEEE N42.55 & $\begin{array}{l}\text { Standard for the Performance of Portable X-Ray Systems for Use in Bomb } \\
\text { Identification }\end{array}$ \\
\hline 17 & ANSI/IEEE C95.4-2002 & $\begin{array}{l}\text { IEEE Recommended Practice for Determining Safe Distances from Radio } \\
\text { Frequency Transmitting Antennas When Using Electric Blasting Caps During } \\
\text { Explosive Operations }\end{array}$ \\
\hline 18 & ASTM F792-08 & $\begin{array}{l}\text { Standard Practice for Evaluating the Imaging Performance of Security X-Ray } \\
\text { Systems }\end{array}$ \\
\hline 19 & ASTM E2740-12 & $\begin{array}{l}\text { Standard Specification for Trash Receptacles Subjected to Blast Resistance } \\
\text { Testing }\end{array}$ \\
\hline 20 & ASTM E2639-12 & Standard Test Method for Blast Resistance of Trash Receptacles \\
\hline 21 & ASTM E2831M-11 & $\begin{array}{l}\text { Standard Guide for Deployment of Blast Resistant Trash Receptacles in Crowded } \\
\text { Places }\end{array}$ \\
\hline 22 & ASTM E2520-07 & $\begin{array}{l}\text { Standard Practice for Verifying Minimum Acceptable Performance of Trace } \\
\text { Explosive Detectors }\end{array}$ \\
\hline 23 & ASTM E2801-11* & $\begin{array}{l}\text { Standard Test Method for Evaluating Emergency Response Robot Capabilities: } \\
\text { Mobility: Confined Area Obstacles: Gaps }\end{array}$ \\
\hline 24 & ASTM E2802-11* & $\begin{array}{l}\text { Standard Test Method for Evaluating Emergency Response Robot Capabilities: } \\
\text { Mobility: Confined Area Obstacles: Hurdles }\end{array}$ \\
\hline 25 & ASTM E2803-11* & $\begin{array}{l}\text { Standard Test Method for Evaluating Emergency Response Robot Capabilities: } \\
\text { Mobility: Confined Area Obstacles: Inclined Planes }\end{array}$ \\
\hline
\end{tabular}




\begin{tabular}{|l|l|l|}
\hline 26 & ASTM E2804-11* & $\begin{array}{l}\text { Ttandard Test Method for Evaluating Emergency Response Robot Capabilities: } \\
\text { Mobility: Confined Area Obstacles: Stairs/Landings }\end{array}$ \\
\hline 27 & ASTM E2826-11* & $\begin{array}{l}\text { Standard Test Method for Evaluating Emergency Response Robot Capabilities: } \\
\text { Mobility: Confined Area Terrains: Continuous Pitch/Roll Ramps }\end{array}$ \\
\hline 28 & ASTM E2827-11* & $\begin{array}{l}\text { Standard Test Method for Evaluating Emergency Response Robot Capabilities: } \\
\text { Mobility: Confined Area Terrains: Crossing Pitch/Roll Ramps }\end{array}$ \\
\hline 29 & ASTM E2828-11* & $\begin{array}{l}\text { Standard Test Method for Evaluating Emergency Response Robot Capabilities: } \\
\text { Mobility: Confined Area Terrains: Symmetric Stepfields }\end{array}$ \\
\hline 30 & ASTM E2829-11* & $\begin{array}{l}\text { Standard Test Method for Evaluating Emergency Response Robot Capabilities: } \\
\text { Mobility: Maneuvering Tasks: Sustained Speed }\end{array}$ \\
\hline 31 & ASTM E2830-11* & $\begin{array}{l}\text { Standard Test Method for Evaluating the Mobility Capabilities of Emergency } \\
\text { Response Robots Using Towing Tasks: Grasped Sleds }\end{array}$ \\
\hline 32 & BSR N42.40-200x & $\begin{array}{l}\text { Standard for Evaluation and Performance of High Energy, X-Ray Interrogation } \\
\text { Systems for Detection of Contraband of Concern in Homeland Security }\end{array}$ \\
\hline 33 & ISO 16934: 2007 & $\begin{array}{l}\text { Glass in Building-Explosion-Resistant Security Glazing-Test and Classification by } \\
\text { Shock-Tube Loading }\end{array}$ \\
\hline 34 & MIL-D-16191F NOT 1 & Detectors, Explosive Vapor \\
\hline
\end{tabular}

Notes:

Highlighted standards have been bundled into one standard as they are complementary components regarding one technology or knowledge area.

* These standards will also be part of the Vehicle-Borne Improvised Explosive Device (VBIED) Robot Standard that is currently under development. 
APPENDIX C

STANDARDS ANALYZED FOR DHS ADOPTION 


\section{APPENDIX C STANDARDS ANALYZED FOR DHS ADOPTION}

Subject-matter experts prepared the following summaries and attempted to provide an overview of the standard. Participants at the federal focus groups and NBSCAB were provided the opportunity to read the full standard prior to discussions or rating.

\section{C.1 NIJ Standard-0603.01: Portable X-Ray Systems for Use in Bomb Identification Summary}

\section{NIJ Standard-0603.01}

\begin{tabular}{|c|c|}
\hline Author & National Institute of Justice \\
\hline Date Published & December 2007 \\
\hline Audience & Owners, operators, and manufacturers of portable x-ray systems \\
\hline Title & Portable X-Ray Systems for Use in Bomb Identification \\
\hline Purpose & $\begin{array}{l}\text { The purpose of this standard is to establish performance requirements and testing } \\
\text { methods for portable x-ray systems for use in bomb disarming operations. This } \\
\text { standard does not apply to cabinet x-ray systems, such as those used for security } \\
\text { screening. }\end{array}$ \\
\hline Summary & $\begin{array}{l}\text { This standard is applicable to battery-powered portable x-ray systems and to } \\
\text { optional-powered (battery or AC-mains) portable x-ray systems. The standard } \\
\text { includes diagrams of a test pattern (figures } 3 \text { and } 4 \text { ) to be used to test the proper } \\
\text { functioning of the system. The pattern involves the specific placement of copper and } \\
\text { tungsten wire and lead pieces behind a } 10-m m \text { piece of steel and a steel wedge, all } \\
\text { mounted on a } 6 \text {-mm-thick piece of acrylic. When testing the image quality of the } \\
\text { portable x-ray system, place the test pattern parallel to and } 10 \mathrm{~mm}( \pm 3 \mathrm{~mm} \text { ) in front } \\
\text { of the image capture unit, and place the x-ray generator module as far away from the } \\
\text { test pattern as recommended by the manufacturer's operational manual for a clear } \\
\text { image on the full image capture unit. Activate the system five times and ensure that } \\
\text { all of the lead, copper, and tungsten are clearly visible in the resulting five images. } \\
\text { Furthermore, the entire image should be clear, within } 12 \mathrm{~mm} \text { of the edge of the } \\
\text { image. To test the power capacity of the system, install fresh batteries and perform } \\
\text { this test once every } 10 \text { minutes. Each image should be completely clear until the } \\
\text { system indicates that the battery should be replaced. } \\
\text { The portable x-ray system should provide an exposure area of } 39.1 \mathrm{~cm} \text { square when } \\
\text { the x-ray generator module is positioned } 59 \mathrm{~cm} \text { ( } \pm 5 \mathrm{~cm} \text { ) away from the target. To test } \\
\text { this, collect nine test patterns and create a } 3 \times 3 \text { grid that is } 480 \mathrm{~mm} \text { high and } \\
660 \text { mm wide. With the x-ray generator module positioned } 59 \mathrm{~cm} \text { ( } \pm 5 \mathrm{~cm} \text { ) away from } \\
\text { the target, acquire the image, and ensure that the field of vision is correct and the } \\
\text { image is clear. } \\
\text { The image acquisition period, which includes any discrete task needed to capture } \\
\text { and display the image, should not exceed } 240 \text { seconds. This time can be measured } \\
\text { with a stopwatch. } \\
\text { Because x-ray generator modules may leak radiation, a qualified individual should } \\
\text { test the amount of leakage in nine specific locations (figure } 2 \text { in the standard). After }\end{array}$ \\
\hline
\end{tabular}




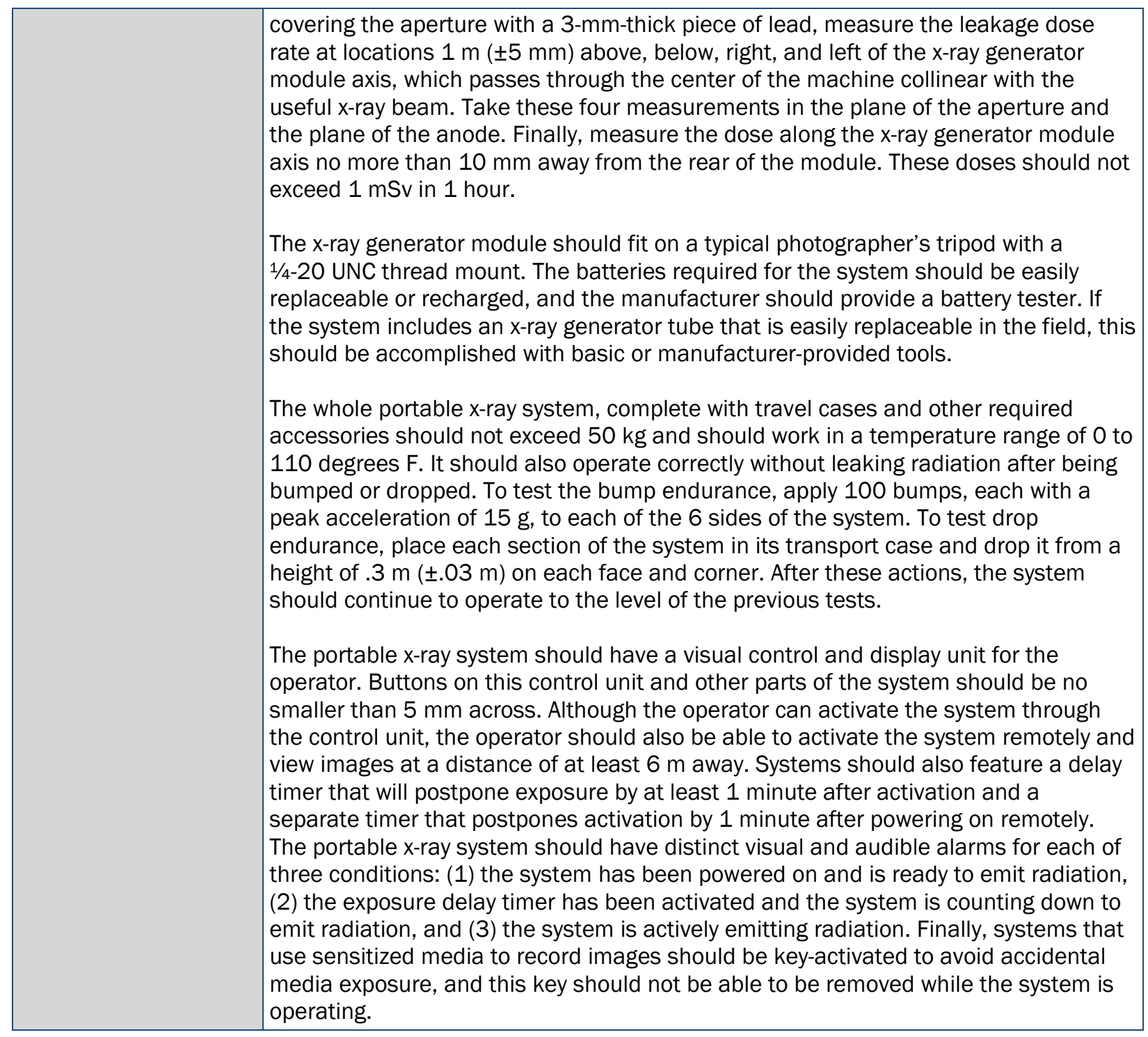

\section{Reference:}

https://www.ncjrs.gov/pdffiles1/nij/218586.pdf

\section{C.2 ASTM Series for Robots}

ASTM Series for Robots: E2801-11, E2802-11, E2803-11, E2804-11, E2826-11, E2827-11, E2828-11, E2829-11, E2830-11

\begin{tabular}{|l|l|}
\hline Author & ASTM International \\
\hline Date Published & 2011 \\
\hline Audience & Owners, operators, and manufacturers of emergency response robots \\
\hline Title & $\begin{array}{l}\text { ASTM Series for Robots: Standard Test Method for Evaluating Emergency Response } \\
\text { Robot Capabilities for: (1) E2801-11, Mobility: Confined Area Obstacles: Gaps; } \\
\text { (2) E2802-11, Mobility: Confined Area Obstacles: Hurdles; (3) E2803-11, Mobility: }\end{array}$ \\
\hline
\end{tabular}




\begin{tabular}{|c|c|}
\hline & $\begin{array}{l}\text { Confined Area Obstacles: Inclined Planes; (4) E2804-11, Mobility: Confined Area } \\
\text { Obstacles: Stairs/Landings; (5) E2826-11, Mobility: Confined Area Terrains: } \\
\text { Continuous Pitch/Roll Ramps; (6) E2827-11, Mobility: Confined Area Terrains: } \\
\text { Crossing Pitch/Roll Ramps; (7) E2828-11, Mobility: Confined Area Terrains: } \\
\text { Symmetric Stepfields; (8) E2829-11, Mobility: Maneuvering Tasks: Sustained Speed; } \\
\text { (9) E2830-11, Mobility Capabilities of Emergency Response Robots Using Towing } \\
\text { Tasks: Grasped Sleds }\end{array}$ \\
\hline Purpose & $\begin{array}{l}\text { The purpose of these nine standard test methods is to quantitatively evaluate the } \\
\text { performance of robots for emergency response applications. These standards are } \\
\text { not specifications for a standard robot of any kind. }\end{array}$ \\
\hline Summary & 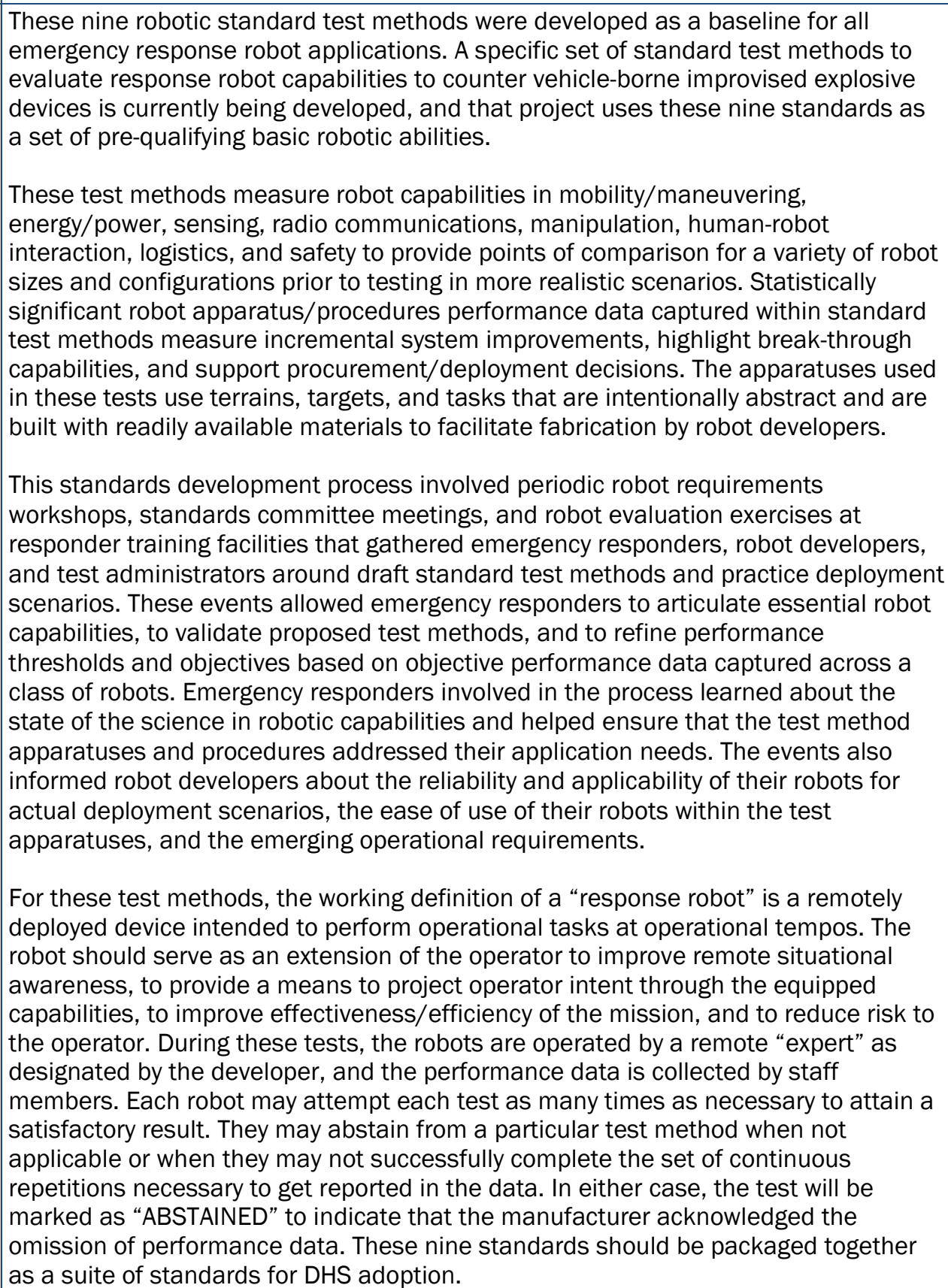 \\
\hline
\end{tabular}


Reference:

http://www.astm.org/Standards/E2801.htm

Reference:

http://www.astm.org/Standards/E2802.htm

Reference:

http://www.astm.org/Standards/E2803.htm

Reference:

http://www.astm.org/Standards/E2804.htm

Reference:

http://www.astm.org/Standards/E2826.htm

Reference:

http://www.astm.org/Standards/E2827.htm

Reference:

http://www.astm.org/Standards/E2828.htm

Reference:

http://www.astm.org/Standards/E2829.htm

Reference:

http://www.astm.org/Standards/E2830.htm

\section{C.3 ASTM E2520-07: Standard Practice for Verifying Minimum Acceptable Performance of Trace Explosive Detectors}

\begin{tabular}{|l|l|}
\hline ASTM E2520-07 & \\
\hline Author & ASTM International \\
\hline Date Published & 2007 \\
\hline Audience & First responders, security screeners, manufacturers/vendors \\
\hline
\end{tabular}




\begin{tabular}{|l|l|}
\hline Title & $\begin{array}{l}\text { ASTM E2520-07: Standard Practice for Verifying Minimum Acceptable Performance } \\
\text { of Trace Explosive Detectors }\end{array}$ \\
\hline Purpose & $\begin{array}{l}\text { This practice is intended primarily to assist first responder and security screeners in } \\
\text { verifying the minimum acceptable performance of trace explosive detectors used to } \\
\text { identify traces of high explosives. The practice can also be used by manufacturers to } \\
\text { demonstrate that the equipment is performing properly to a minimum standard. }\end{array}$ \\
\hline Summary & $\begin{array}{l}\text { This practice is used to demonstrate that detectors used to identify traces of high } \\
\text { explosives by use of a test swipe meet a minimum acceptable performance. This } \\
\text { practice is used to evaluate the detector response to evaporated residues of } \\
\text { low-concentration solution of explosive compounds placed on test swipes. The } \\
\text { concentrations of the solutions of explosive have been determined to be sufficient to } \\
\text { provide a positive detector alarm signal. This practice uses three explosive } \\
\text { compounds-RDX, PETN, and TNT-that are used to represent nitro-based } \\
\text { compounds having a range of physical and chemical properties. This practice was } \\
\text { developed using ion mobility spectrometry-based trace explosive detectors, but this } \\
\text { practice should also be applicable to any explosive detector designed to analyze } \\
\text { trace levels of high-explosive compounds collected on swipes. } \\
\text { The practice may be used to accomplish several ends: to compare detectors before } \\
\text { purchase; as a demonstration by the vendor that the equipment is performing } \\
\text { properly to a minimum standard; or for a periodic verification of detector } \\
\text { performance after purchase. This practice establishes the minimum performance } \\
\text { that is required for a detector to be considered effective and is considered to have } \\
\text { "minimum acceptable performance" when it has passed all of the evaluation tests } \\
\text { without a failure. } \\
\text { This practice outlines the necessary performance evaluation materials (test kits), } \\
\text { procedures, analysis of the test swipes, and documentation of the test procedures. }\end{array}$ \\
\hline
\end{tabular}

Reference:

http://www.astm.org/Standards/E2520.htm

\section{C.4 ASTM Blast Resistant Receptacle Series}

ASTM Series for Blast Resistant Trash Receptacles: E2639-12, E2740-12, E2831M-11

\begin{tabular}{|l|l|}
\hline Author & ASTM International \\
\hline Date Published & 2011, 2012 \\
\hline Audience & Managers with public assembly areas, manufacturers, and test laboratories \\
\hline Title & ASTM E2639-12: Standard Test Method for Blast Resistance of Trash Receptacles \\
\hline Purpose & $\begin{array}{l}\text { This test method provides a procedure for characterizing the performance of a trash } \\
\text { receptacle when an explosive is detonated within the receptacle. }\end{array}$ \\
\hline Summary & $\begin{array}{l}\text { ASTM E2639 is a test method that provides a procedure for measuring the } \\
\text { magnitude of an explosion when the explosion is detonated inside a trash } \\
\text { receptacle. The procedure determines the extent and location of fragments produced } \\
\text { during the explosion and whether breaches are created in the exterior surfaces of } \\
\text { the trash receptacle. An appendix provides guidance for determining the magnitude } \\
\text { of blast waves (that is, external overpressures). } \\
\text { This test procedure is used to measure two of the main effects of an explosive } \\
\text { detonated in a trash receptacle as related to the type and amount of explosive }\end{array}$ \\
\hline
\end{tabular}




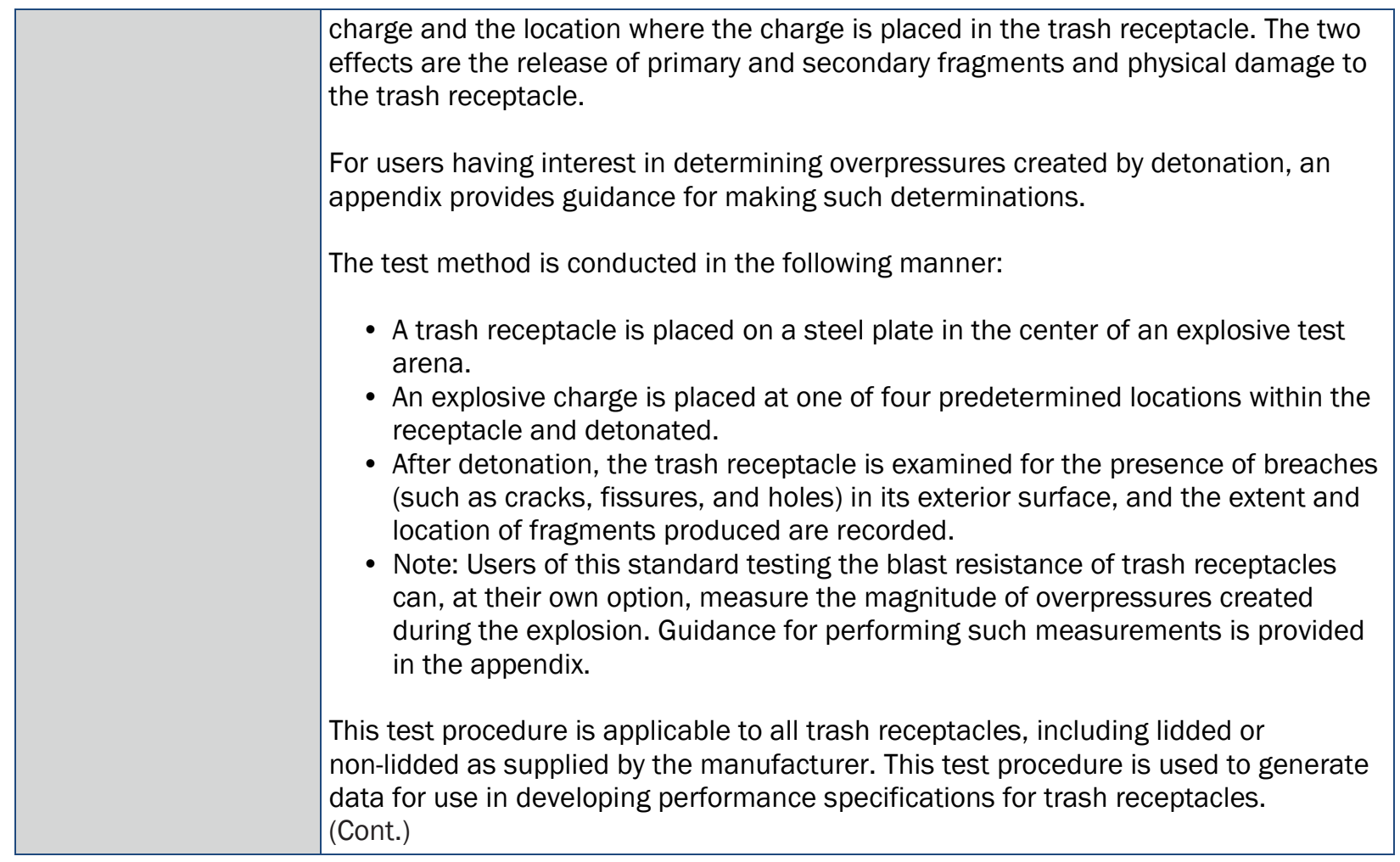

\section{Reference:}

\section{http://www.astm.org/Standards/E2639.htm}

\begin{tabular}{|l|l|}
\hline ASTM Series for Blast Resistant Trash Receptacles (Continued) \\
\hline Title & $\begin{array}{l}\text { ASTM E2740-12: Standard Specification for Trash Receptacles Subjected to Blast } \\
\text { Resistance Testing }\end{array}$ \\
\hline Purpose & $\begin{array}{l}\text { This specification provides performance requirements for trash receptacles when } \\
\text { subjected to the explosive tests described in ASTM E2639. }\end{array}$ \\
\hline $\begin{array}{l}\text { The trash receptacle test specimens shall be tested according to the requirements of } \\
\text { Test Method E2639. Each test specimen shall be tested separately from the others } \\
\text { in the group submitted with the charge at one of three locations. The testing } \\
\text { laboratory shall randomly select the individual test specimen for each test from the } \\
\text { group submitted. }\end{array}$ \\
$\begin{array}{l}\text { Trash receptacles including accessory components shall be tested as supplied by the } \\
\text { manufacturer for in-use service. For example, if the trash receptacle is intended to } \\
\text { have a lid in service, it shall be tested with the lid in place. The lid shall be secured to } \\
\text { the receptacle as recommended by the manufacturer. The mass of the explosive } \\
\text { charge shall be the same for all test specimens in the group submitted. (Cont.) }\end{array}$ \\
\hline
\end{tabular}

\section{Reference:}

http://www.astm.org/Standards/E2740.htm 


\section{ASTM Series for Blast Resistant Trash Receptacles (Continued)}

\begin{tabular}{|l|l|}
\hline Title & $\begin{array}{l}\text { ASTM E2831M-11: Standard Guide for Deployment of Blast Resistant Trash } \\
\text { Receptacles in Crowded Places }\end{array}$ \\
\hline Purpose & $\begin{array}{l}\text { This standard provides guidance on the deployment of blast resistant trash } \\
\text { receptacles because the selection of deployment locations impacts both the } \\
\text { mitigation of the effects of an explosion occurring within one as well as the } \\
\text { convenience of using the receptacles. }\end{array}$ \\
\hline $\begin{array}{l}\text { This guide provides general provisions for the deployment of blast resistant trash } \\
\text { receptacles. Each facility or venue has unique features associated with factors such } \\
\text { as demographics, location, and functions. The guide identifies key factors that } \\
\text { should be considered prior to the receptacle deployment (in interior and exterior } \\
\text { locations) and discusses the facilities and venues where the receptacles should be } \\
\text { deployed. }\end{array}$ & $\begin{array}{l}\text { The importance of a strategy and procedures for the deployment of blast resistant } \\
\text { trash receptacles in crowded places cannot be overly emphasized. Trash receptacles } \\
\text { in crowded places have been, and continue to be, an attractive repository for } \\
\text { explosives. The selection of deployment locations impacts both the mitigation of the } \\
\text { effects of an explosion occurring within one as well as the convenience of using the } \\
\text { receptacles. }\end{array}$ \\
$\begin{array}{l}\text { The deployment of blast resistant trash receptacles provides a means for decreasing } \\
\text { injury and lethality during an explosive event, no matter their location when } \\
\text { compared to the protection afforded by ordinary trash receptacles or clear plastic } \\
\text { bags. Fragments resulting from explosions create the greatest danger to people, as } \\
\text { fragments may travel several hundred meters and still have velocities that could be } \\
\text { lethal or injurious. Blast resistant trash receptacles that meet the requirements of } \\
\text { ASTM E2740-10 when subjected to internal explosions equal to or less than the } \\
\text { force protection rating contain horizontal primary fragments and do not produce } \\
\text { secondary fragments. } \\
\text { The guide is intended for use by individuals in both the private and public sectors } \\
\text { who are considering the purchase and deployment of blast resistant trash } \\
\text { receptacles. }\end{array}$ \\
\hline
\end{tabular}

Reference:

http://www.astm.org/Standards/E2831.htm

\section{C.5 National Guidelines for Bomb Technicians}

\section{National Guidelines for Bomb Technicians 2012}

\begin{tabular}{|l|l|}
\hline Author & National Bomb Squad Commanders Advisory Board/Federal Bureau of Investigation \\
\hline Date Published & March 2010 \\
\hline Audience & U.S. civilian bomb technicians \\
\hline Title & National Guidelines for Bomb Technicians 2012 \\
\hline Purpose & Law enforcement sensitive \\
\hline Summary & Law enforcement sensitive \\
\hline
\end{tabular}


http://nbscab.org/NBSCAB/nbscab ex.php

\section{C.6 ASTM F792-08: Standard Practice for Evaluating the Imaging Performance of Security X-Ray Systems}

\begin{tabular}{|c|c|}
\hline \multicolumn{2}{|l|}{ ASTM F792-08 } \\
\hline Author & ASTM International \\
\hline Date Published & 2008 \\
\hline Audience & X-ray manufacturers and security evaluators \\
\hline Title & Standard Practice for Evaluating the Imaging Performance of Security X-Ray Systems \\
\hline Purpose & $\begin{array}{l}\text { The purpose of this practice is to establish a method to measure the imaging } \\
\text { performance of x-ray systems used for the screening of prohibited items in baggage, } \\
\text { packages, cargo, or mail. }\end{array}$ \\
\hline Summary & 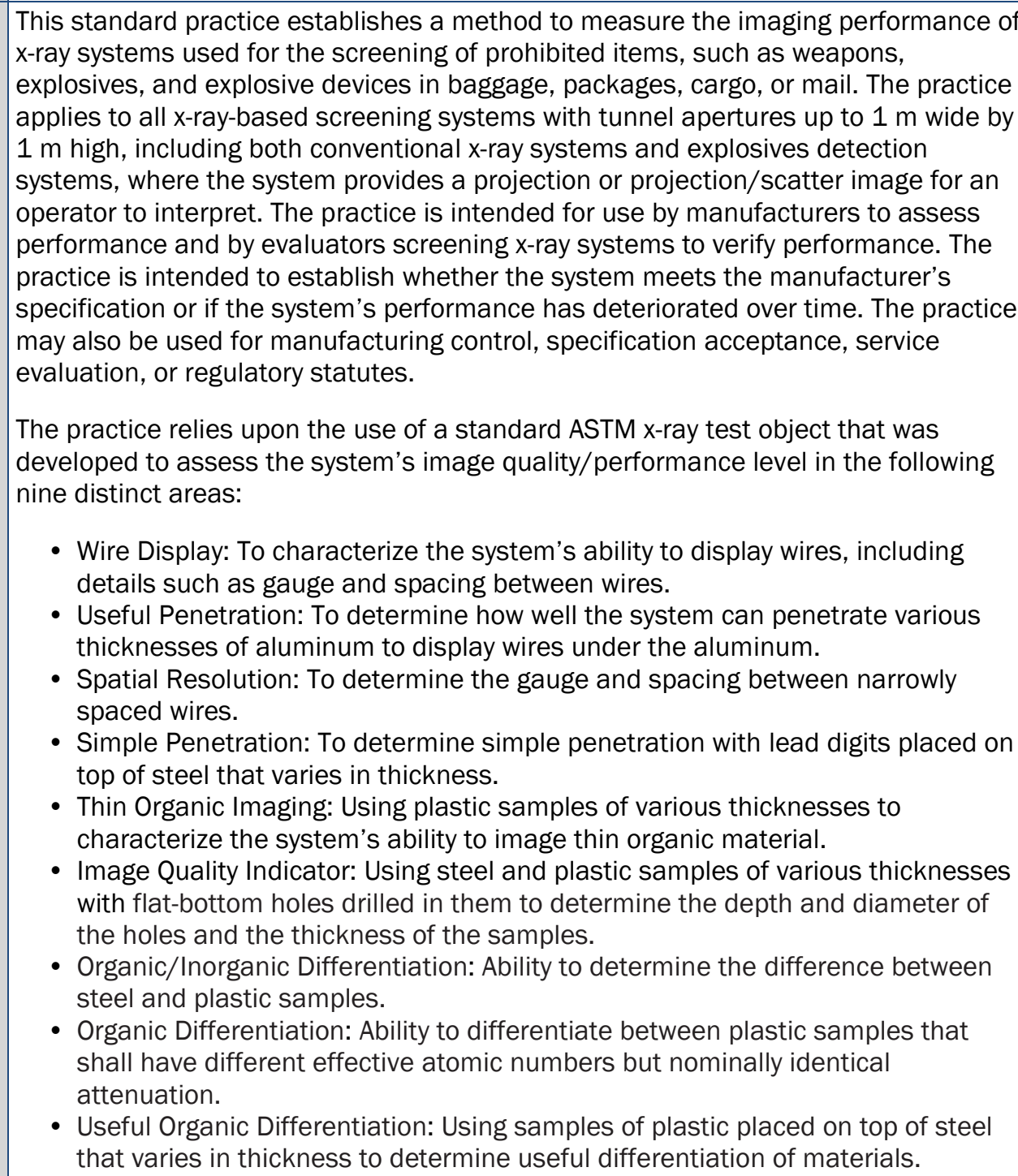 \\
\hline
\end{tabular}


This practice establishes quantitative and qualitative methods for evaluating the systems but does not establish minimum performance requirements for any particular application. The practice lists the specific testing procedures and outlines numerous evaluation considerations.

Reference:

www.astm.org/Standards/F792.htm

\section{C.7 NIJ Standard-0117.00: Public Safety Bomb Suit Standard}

\section{NIJ Standard-0117.00}

\begin{tabular}{|c|c|}
\hline Author & $\begin{array}{l}\text { U.S. Department of Justice, Standards and Testing Program, Office of Justice } \\
\text { Programs, National Institute of Justice }\end{array}$ \\
\hline Date Published & March 2012 \\
\hline Audience & Certified public safety bomb technicians \\
\hline Title & Public Safety Bomb Suit Standard \\
\hline Purpose & $\begin{array}{l}\text { The purpose of this standard is to specify minimum voluntary performance } \\
\text { requirements for bomb suits and to outline the associated certification program } \\
\text { test methods for assessing that the performance requirements are met. This } \\
\text { standard is for bomb suits used by certified public safety bomb technicians while } \\
\text { performing hazardous device render safe procedures and assessing potential } \\
\text { suspicious items. A second related document (Certification Program Requirements) } \\
\text { defines the methods used to test the performance requirements, and a third } \\
\text { document (Selection and Application Guide) is available to provide guidance on } \\
\text { selecting, procuring, using, and maintaining bomb suits. Since this standard is a } \\
\text { performance and testing standard, it provides precise and detailed test methods. }\end{array}$ \\
\hline Summary & $\begin{array}{l}\text { This standard is a Voluntary Performance Standard with an accompanying } \\
\text { Certification Program Requirements document. The standard addresses six key } \\
\text { areas: fragmentation, impact, flame, blast overpressure, optics, and ergonomics. } \\
\text { Fragmentation, impact, flame, and blast overpressure are hazards that a bomb } \\
\text { technician needs protection from when performing render safe procedures. Optics } \\
\text { and ergonomics relate to a bomb technician's ability to perform render safe } \\
\text { procedures while wearing the bomb suit. The standard balances the protection } \\
\text { requirements against the bomb technician's need for mobility, clear vision, and } \\
\text { dexterity. Within the six key areas, all bomb suit models shall meet or exceed the } \\
\text { applicable performance requirements specified in the categories below. } \\
\text { - Ergonomics: Donning/doffing, body mobility } \\
\text { - Optics: Distortion, refraction, anti-fogging } \\
\text { - Flammability: Outer shell materials and helmets } \\
\text { - Electrostatic discharge: Grounding strap requirements } \\
\text { - Head protection: Impact, perforation resistance, and retention system } \\
\text { - Fragmentation: Perforation resistance } \\
\text { - Blast integrity: Ability to remain intact when subject to blast overpressure } \\
\text { - Drag rescue: Handles to provide drag ability for downed bomb technician } \\
\text { - Label durability: Wear and chemical resistance } \\
\text { - Optional foot protection slip resistance } \\
\text { All bomb suits used when testing against this standard shall be new. The bomb } \\
\text { suits shall be designed to protect at least the wearer's head, face, neck, }\end{array}$ \\
\hline
\end{tabular}




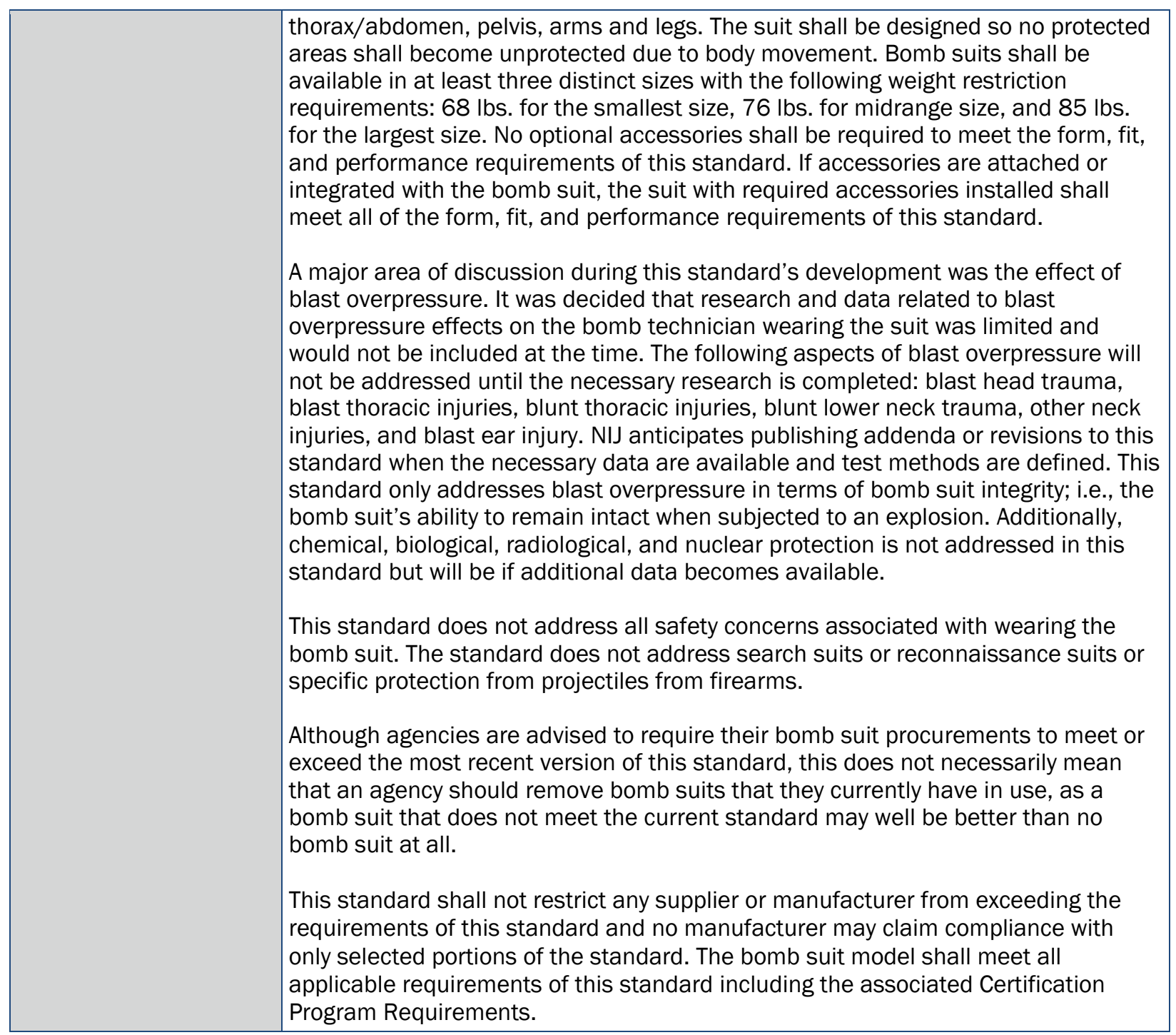

Reference:

https://www.ncjrs.gov/pdffiles1/nij/227357.pdf

\section{C.8 ANSI N42.47-2010: American National Standard for Measuring the Imaging Performance of X-Ray and Gamma-Ray Systems for Sec urity Screening of Humans}

\section{ANSI N42.47-2010}

\begin{tabular}{|l|l|}
\hline Author & $\begin{array}{l}\text { National Committee on Radiation Instrumentation, American National Standards } \\
\text { Institute, Institute of Electrical Electronics Engineers, Inc. }\end{array}$ \\
\hline Date Published & August 2010 \\
\hline Audience & X-ray and gamma-ray system manufacturers, potential system users, and other \\
\hline
\end{tabular}




\begin{tabular}{|c|c|}
\hline & interested parties \\
\hline Title & $\begin{array}{l}\text { American National Standard for Measuring the Imaging Performance of X-Ray and } \\
\text { Gamma-Ray Systems for Security Screening of Humans }\end{array}$ \\
\hline Purpose & $\begin{array}{l}\text { This standard applies to security screening systems that utilize x-ray or gamma } \\
\text { radiation and are used to inspect people who are not inside vehicles, containers, or } \\
\text { enclosures. Specifically, this standard applies to systems used to detect objects } \\
\text { carried on or within the body of the individual being exposed. The purpose of this } \\
\text { standard is to provide standard methods of measuring and reporting imaging } \\
\text { quality characteristics and to establish minimum acceptable performance } \\
\text { requirements. }\end{array}$ \\
\hline Summary & 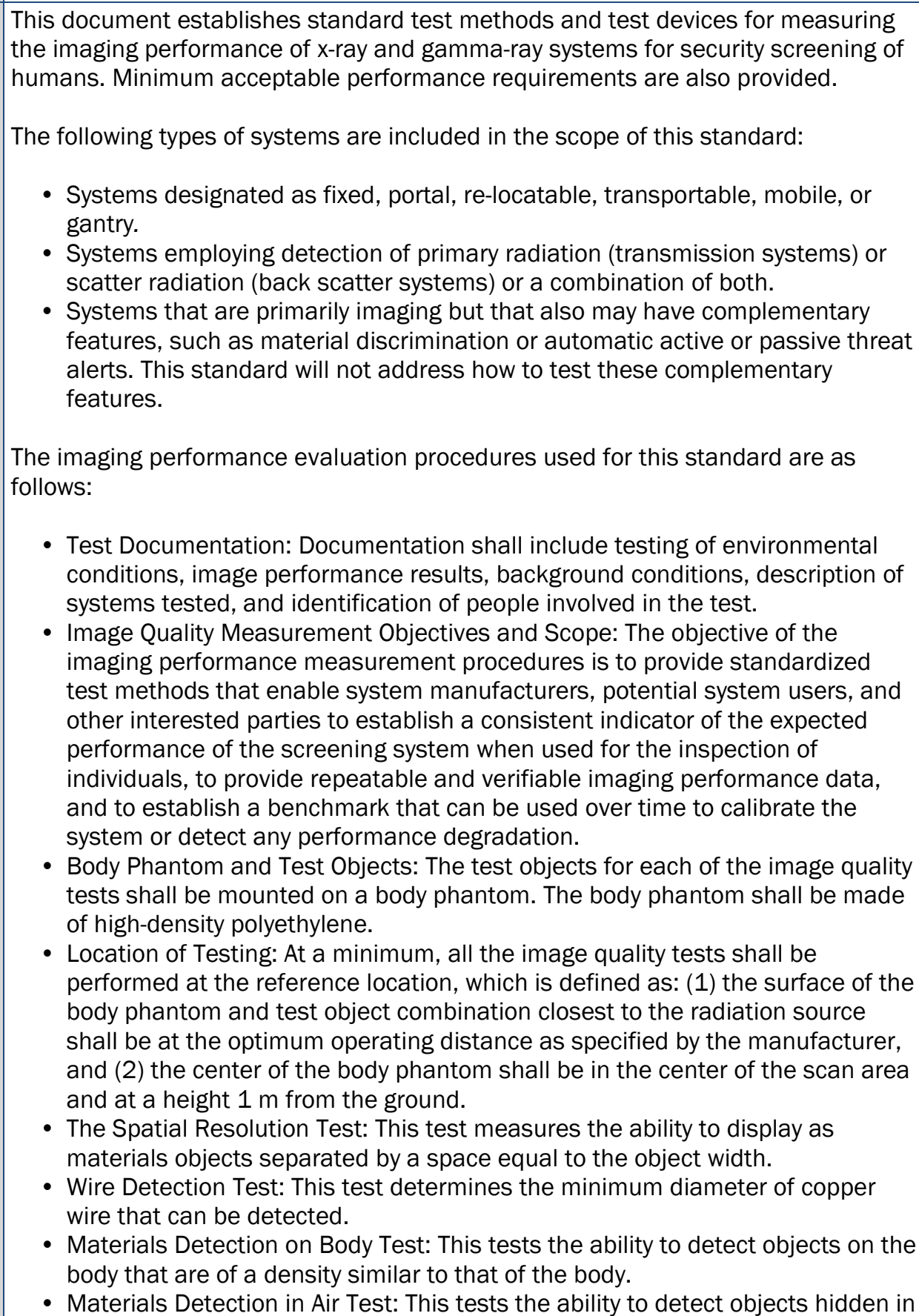 \\
\hline
\end{tabular}




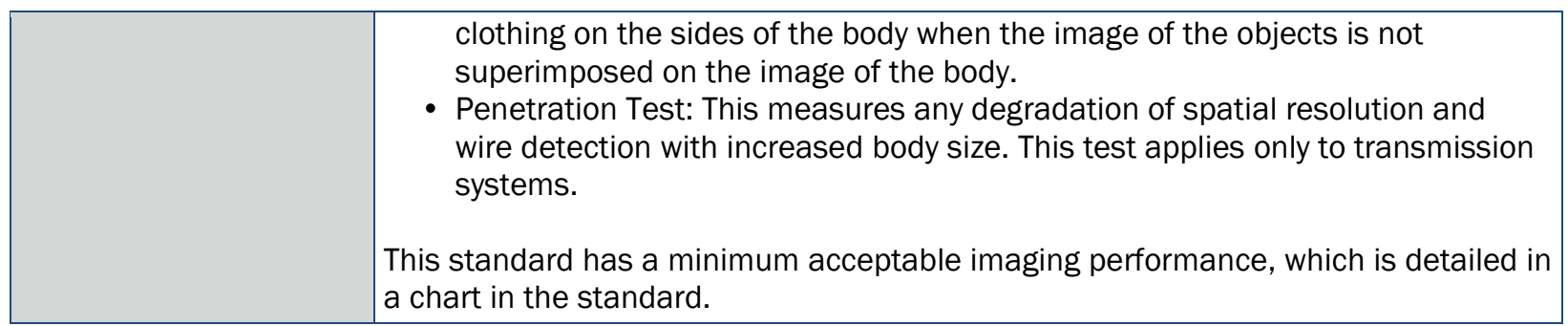

\section{Reference:}

\section{http://ieeexplore.ieee.org/servlet/opac?punumber $=5557723$}

\section{C.9 ANSI N42.44: Performance of Checkpoint Cabinet X-Ray Imaging Security Systems}

\begin{tabular}{|c|c|}
\hline \multicolumn{2}{|c|}{ ANSI N42.44-2008 } \\
\hline Author & $\begin{array}{l}\text { National Committee on Radiation Instrumentation, American National Standards } \\
\text { Institute, Institute of Electrical and Electronics Engineers, Inc. }\end{array}$ \\
\hline Date Published & November 2008 \\
\hline Audience & $\begin{array}{l}\text { X-ray and gamma-ray system manufacturers, potential system users, and other } \\
\text { interested parties }\end{array}$ \\
\hline Title & $\begin{array}{l}\text { American National Standard for the Performance of Checkpoint Cabinet X-Ray } \\
\text { Imaging Security Systems }\end{array}$ \\
\hline Purpose & $\begin{array}{l}\text { Screeners frequently use the images provided by checkpoint x-ray systems to } \\
\text { detect weapons and contraband materials as well as to verify manifests (to } \\
\text { determine that the contents of a package are what they are purported to be). For } \\
\text { these applications, this standard is intended to provide procurers and/or } \\
\text { prospective users of checkpoint x-ray systems with test methods that facilitate } \\
\text { performance comparisons among systems and the minimum acceptable } \\
\text { imaging-performance requirements. Additionally, a variety of factors essential for } \\
\text { the safe operation of checkpoint x-ray systems are assembled and standardized in } \\
\text { this document. }\end{array}$ \\
\hline Summary & $\begin{array}{l}\text { This standard specifies minimum requirements and test procedures for x-ray } \\
\text { imaging performance, radiation-limitation requirements, and electrical, mechanical, } \\
\text { and environmental requirements. This standard addresses technical image-quality } \\
\text { performance, not threat-detection performance. } \\
\text { The test object used in this document is composed of fixtures for the following nine } \\
\text { tests: } \\
\text { - Test 1: Wire display; } \\
\text { - Test 2: Useful penetration; } \\
\text { - Test 3: Spatial resolution; } \\
\text { - Test 4: Simple penetration; } \\
\text { - Test 5: Thin organic imaging; } \\
\text { - Test 6: Image-quality-indicator sensitivity; } \\
\text { - Test 7: Organic/inorganic differentiation; } \\
\text { - Test 8: Organic differentiation; and }\end{array}$ \\
\hline
\end{tabular}




\begin{tabular}{|l|l|}
\hline \multicolumn{1}{|c|}{ Test 9: Useful organic differentiation. } \\
The use of non-tinned, solid copper wires is required for Test 1, Test 2, and Test 3 \\
in this standard. \\
The test object shall be placed alone and in its case such that one surface of the \\
case is in contact with the x-ray conveyor belt. The surface in contact with the \\
conveyor belt should be chosen such that the test object is more nearly \\
perpendicular to the x-ray beam axis. Thus, if the x-ray beam is primarily directed \\
vertically upward (“up-shooter"), the case should lie flat; if the x-ray beam is \\
primarily directed horizontally ("side shooter"), the case should be positioned on \\
edge. An exception is permitted for systems in which the x-ray beam is primarily \\
directed vertically downward ("down-shooter"), for which the test object shall be \\
positioned with the bottom surface of the case parallel to the conveyor surface but \\
may be elevated to a height above the conveyor belt of up to one-fourth of the \\
vertical tunnel dimension. In all cases, the test object (in its case) shall be scanned \\
with its long dimension parallel to the direction of the conveyor motion. The case \\
may be positioned laterally (with respect to the direction of the conveyor motion) for \\
optimal performance in any test. In all cases, the placement and orientation of the \\
test object shall be reported in the test procedure with the corresponding test \\
results. \\
The tests specified in this standard may be used for type testing. Type tests are \\
intended to demonstrate that production systems made according to a specific \\
design meet defined performance criteria.
\end{tabular}

Reference:

http://ieeexplore.ieee.org/servlet/opac?punumber $=4667698$

\section{C.10 ANSI N42.45: Standard for Evaluating the Image Quality of X-Ray Computed Tomography (CT) Security Screening Systems}

\begin{tabular}{|l|l|}
\hline ANSI N42.45-2011 & Institute of Electrical and Electronics Engineers, Inc. \\
\hline Author & 2011 \\
\hline Date Published & $\begin{array}{l}\text { Owners, operators, and manufacturers of computed tomography (CT) } \\
\text { security-screening systems }\end{array}$ \\
\hline Audience & $\begin{array}{l}\text { American National Standard for Evaluating the Image Quality of X-Ray Computed } \\
\text { Tomography (CT) Security-Screening Systems }\end{array}$ \\
\hline Pitle & $\begin{array}{l}\text { This standard provides test methods for the evaluation of image quality of CT } \\
\text { security-screening systems. The quality of data for automated analysis is the } \\
\text { primary concern. This standard does not address the system's ability to use this } \\
\text { image data to automatically detect explosives or other threat materials, which is } \\
\text { typically verified by an appropriate regulatory body. }\end{array}$ \\
\hline Summary: & $\begin{array}{l}\text { Security screening systems are generally used to scan parcels, including luggage, } \\
\text { for the presence of illicit items such as explosives, drugs, or other contraband. } \\
\text { Many of the screening systems currently used, particularly in transportation security } \\
\text { applications, are based on CT imaging technology. Generally, as the parcel is } \\
\text { transported through the system, the system collects a CT image of the parcel. This } \\
\text { data is then subjected to automated analysis to determine whether a threat may be } \\
\text { present or the parcel is considered clear. If the automated analysis determines a }\end{array}$ \\
\hline
\end{tabular}




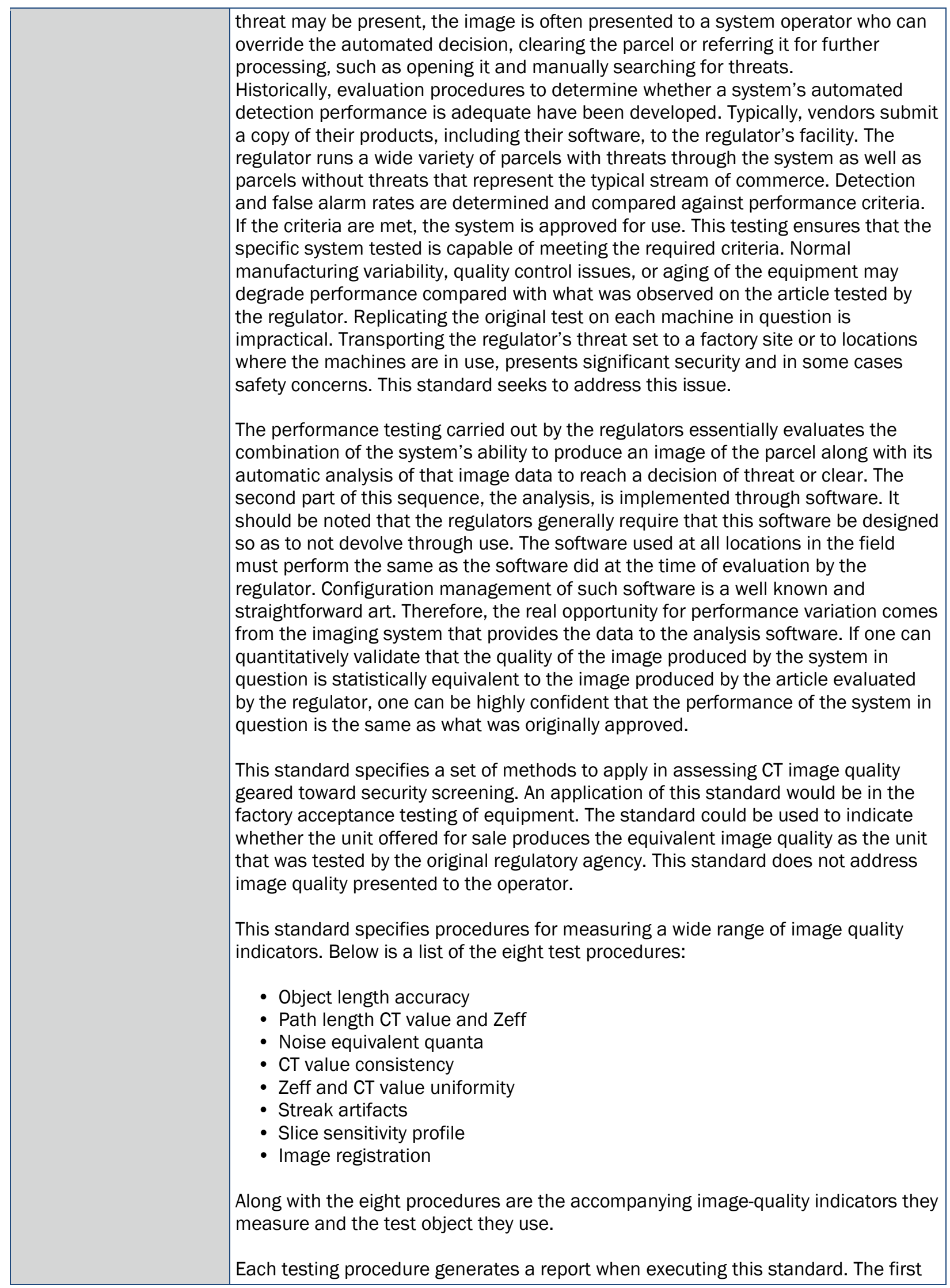


part of the report is manually recorded observations of the test environment. The second part is the result of analysis of test article $A$, and the third part is from the analysis of test article $B$.

Reference:

http://ieeexplore.ieee.org/servlet/opac?punumber $=5783277$

\section{C.11 ANSI N42.46: Determination of the Imaging Performance of X-Ray and Gamma Systems for Cargo and Vehicle Security}

Screening

\section{ANSI N42.46-2008}

\begin{tabular}{|c|c|}
\hline Author & Institute of Electrical and Electronics Engineers, Inc. \\
\hline Date Published & 2008 \\
\hline Audience & $\begin{array}{l}\text { Owners, operators, and manufacturers of x-ray and gamma-ray systems for cargo } \\
\text { and vehicle security screening }\end{array}$ \\
\hline Title & $\begin{array}{l}\text { American National Standard for Determination of the Imaging Performance of X-Ray } \\
\text { and Gamma-Ray Systems for Cargo and Vehicle Security Screening }\end{array}$ \\
\hline Purpose & $\begin{array}{l}\text { The purpose of this document is to provide standard, repeatable, and verifiable } \\
\text { methods to describe and measure the imaging performance characteristics of x-ray } \\
\text { and gamma-ray systems for cargo and vehicle security screening. It is not intended } \\
\text { to determine the capability of a security screening system under specific } \\
\text { operational inspection conditions. }\end{array}$ \\
\hline Summary & $\begin{array}{l}\text { This standard is intended to be used to determine the imaging performance of x-ray } \\
\text { and gamma-ray systems utilized to inspect loaded or empty vehicles, including } \\
\text { personal and commercial vehicles of any type, marine and air cargo containers of } \\
\text { any size, railroad cars, and palletized or un-palletized cargo larger than } 1 \mathrm{~m} \times 1 \mathrm{~m} \\
\text { in cross-section. The standard applies to systems that: } \\
\text { - Are single or multiple energy, source, or view; } \\
\text { - Employ primary (i.e., transmission) and/or scatter (e.g., backscatter) radiation } \\
\text { detection; } \\
\text { - Detect prohibited and controlled materials and/or verify manifests; and } \\
\text { - Serve primarily as imaging systems but that also may have complementary } \\
\text { features, such as material discrimination and automatic active or passive } \\
\text { threat alerts. This standard does not address how to test these } \\
\text { complementary features. } \\
\text { The below are the Performance Measurement Procedures that shall be consistent } \\
\text { for all systems of similar type or size: } \\
\text { - General Requirements: Test objects and measurement procedures may differ } \\
\text { to some extent depending on the type of imaging system (e.g., transmission or } \\
\text { backscatter) or system size. Test objects and procedures shall be consistent } \\
\text { for all systems of similar type or size. } \\
\text { - Standard Test Conditions: The tests defined in this standard should be } \\
\text { performed on the standard commercial product as provided by the } \\
\text { manufacturer. }\end{array}$ \\
\hline
\end{tabular}




\begin{tabular}{|l|l|}
\hline - Radiation Field Measurement: The x-ray and gamma-ray systems that are the \\
subject of this standard use ionizing radiation to create an image of cargo and \\
vehicles. For purposes of this standard, the resulting radiation field in and \\
around the system and the radiation dose received by the inspected object \\
also shall be measured as part of the characterization of system performance. \\
- Documentation: All testing environmental conditions, measurements, \\
description of systems, etc. shall be documented, retained, and available for \\
inspection for as long as any systems similar to those tested remain in service. \\
- Image Quality Measurement Objectives and Scope: The objectives are to \\
establish a consistent indicator of the expected performance of the screening \\
system when used for the inspection of cargo and vehicles, to provide \\
repeatable and verifiable imaging performance data, and to establish a \\
benchmark that can be used over time to calibrate the system or to detect any \\
performance degradation. \\
- Test Object Positions: At a minimum, all tests shall be performed at a \\
horizontal and vertical location. \\
- Penetration: The test should measure the maximum thickness of steel through \\
which the orientation of a specified test object can be determined. \\
Spatial Resolution: The test should measure the minimum separation between \\
the features of a test object for which the individual features can be \\
distinguished \\
- Wire Detection: The test should determine the smallest diameter wires that \\
are visible in the x-ray or gamma-ray image. The test objects and test \\
procedures differ for transmission and backscatter imaging. In both cases, the \\
test measures the minimum diameter copper wire that is visible in the image \\
of a test object scanned in air. \\
Contrast Sensitivity: The test should measure the minimum increase in steel \\
thickness visible in an x-ray or gamma-ray image. The test objects and \\
procedures differ for transmission and backscatter imaging.
\end{tabular}

\section{Reference:}

http://ieeexplore.ieee.org/servlet/opac?punumber $=4606805$ 